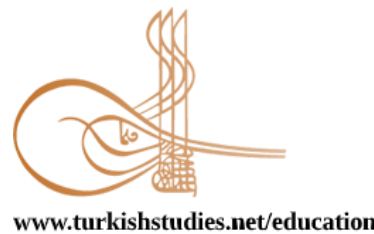

Turkish Studies - Educational Sciences

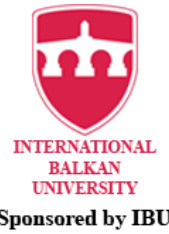

ResearchArticle / Araștırma Makalesi

\title{
STEM Eğitiminin Fen Bilgisi Öğretmen Adaylarının Problem Çözme Becerilerine Etkisi*
}

\author{
The Effect of STEM Education on Pre-Service Science Teachers' Problem Solving Skills
}

\author{
Safiye Ceren Öztürk** - Sema Altun Yalçın ***
}

\begin{abstract}
The purpose of this research; to examine the effect of STEM education on pre service svience teachers' problem solving skills. For this purpose, lessons and interviews with STEM applications were held with 30 preservice teachers studying in Erzincan Binali Yıldırım University, Faculty of Education, Department of Science Education. In the study using mixed method; In order to measure problem solving skills with quantitative data, the problem solving scale was applied as a single group pretest-posttest. In order to obtain qualitative data, focus group interview technique was applied. During the focus group interview, open-ended questions were used by the researcher, which could contribute to the detailed research of quantitative data. The questions were prepared in parallel with the sub-dimensions of the scale used for this purpose, and the expert opinion was obtained and finalized. In the study, it was determined that STEM education has a positive contribution to the development of pre-service teachers' problem solving skills. In the development of pre-service teachers' problem solving skills; It was determined that they thought it was because they had to solve the problems they encountered during STEM education. It has been determined that they think that STEM Education has an effect on some of the individual characteristics that form the basis of problem solving skills. These; They stated that they are willing, patient and courageous against problem solving, taking responsibility, making decisions, expressing their ideas freely even to people with opposite thoughts and defending when necessary. It is also stated that STEM contributes to a wide variety of new developments in individuals with its versatile structure. They think that they will contribute to both their own development and the students they will teach. They emphasized that STEM is an effective method for generating solutions to real-life problems and discovering and developing multi-faceted solutions, as it provides individuals with interdisciplinary thinking skills, provides experiences in working in cooperation, and provides a basis for finding solutions to life-related problem.
\end{abstract}

Structured Abstract: Introduction: This research aims to investigate the effect of STEM education on the problem-solving skills of pre-service science teachers. Problems are the situations that individuals encounter in their lives and solve by using their knowledge and experiences (Olkun \& Toluk, 2001: 32). Problems are described

\footnotetext{
* Bu çalışma, 2018 yılında yayınlanan yüksek lisans tezinden türetilmiş olup, 9-10-11 Mayıs 2018 tarihlerinde "VIII. Uluslararası Eğitimde Araştırmalar Kongresi (ULEAD 2018 ANNUAL CONGRESS, VIII. International Congress on Research in Education -ICRE)" nde sunulmuştur.

** Yüksek Lisans Öğrencisi, Erzincan Üniversitesi, Fen Bilimleri Enstitüsü, Fen Eğitimi

Graduate Student, Erzincan University, Institute of Science, Science Education

ORCID 0000-0003-1014-6778

s.cerenozturk@hotmail.com

*** Prof. Dr., Erzincan Üniversitesi, Eğitim Fakültesi, Fen Bilgisi Öğretmenliği

Prof. Dr., Erzincan University, Faculty of Education, Science Education

ORCID 0000-0001-6349-2231

saltun_11@ hotmail.com

Cite as/ Atıf: Öztürk, S. C. \& Altun Yalçın, S. (2020). STEM eğitiminin fen bilgisi öğretmen adaylarının problem

çözme becerilerine etkisi. Turkish Studies - Education, 15(4), 2893-2915.

https://dx.doi.org/10.47423/TurkishStudies.43707

Received/Geliş: 12 March/Mart 2020

Accepted/Kabul: 02 September/Eylül 2020

Copyright (C) INTACLTD, Turkey

Checked by plagiarism software

Published/Yayın: 30 August/Ağustos 2020

CC BY-NC 4.0
} 
as situations including mental processes suddenly confronting individuals in reaching a purpose. It necessitates to removing obstacles on the way to the solution. In this direction, it is necessary for the individual who is faced with a problem during the solving process to make his/her effort, take the risks if necessary instead of expecting others to make a decision, solve the problem or help. Thanks to this, they can develop their skills in a variety of thought to express themselves with self-confidence (Bingham, 2004: 55). In daily life, these individuals are highly competent in creating solutions, more engaged in communicating, have a positive self, and demonstrate behaviours with an academically successful perception (Şahin vd., 1993: 384). Teachers, who have advanced skills in thinking, are needed. Educating teachers to improve their skills will be beneficial for them (Loughran, 2002: 39). In addition to this view, it is stated that these qualifications should be gained to teachers before students (Wilks, 1995). The attitudes and behaviours of teachers affect their students. Students, mostly, pay attention to their teachers' attitudes and their interpretations of the events rather than the topics they teach and are affected by all their behaviours (Varış, 1998:132). In this sense, the lessons, that teachers took during their school years as students, affect their professional lives (Can, 1987:162).

\section{Method}

In this research, which was carried out with 30 pre-service teachers at the 3rd class of the Science Teaching Department, the exploratory mixed-method was employed. The quantitative method of the research consists of the single group pretest-posttest weak experimental pattern. For the quantitative data, the "Problem Solving Inventory" was applied. The inventory was developed by Heppner and Peterson (1982) and adapted to Turkish by Akkoyun and Öztan (1988 akt. Taylan 1990). As the qualitative method, the focus group protocol technique was applied. Open-ended questions, which could predict quantitative data andprepared by the researcher, were used during the focus group protocol.

\section{Process}

In selecting this applications and events, mainly including full STEM education attention was paid to the fact that the pre-service teacherswould create different and interesting designs by using their content knowledge to produce new things and to solve the problems they encountered with their knowledge, experience and efforts, and use them in teaching environments in their professional life. STEM was realized in a way that includes different forms of education, that is, especially from parts, in everyday life, with the materials they encounter and the integration of lego, coding, robotics, web 2 tools.

\section{Result and Discussion}

In the research, it was found that the problem-solving skills of pre-service teachers were developed with STEM education. In addition, it was determined that the pre-service teachers had opinions that STEM education can develop many high-level skills such as problem-solving. It was also determined with the expressions of the pre-service teachers that they showed positive development. Besides, it was demonstrated that STEM contributes to various new developments in individuals with its multi-dimensional structure. Thanks to the STEM activities, the pre-service teachers expressed that sophisticated thinking skills including practical intelligence were revealed. They describeit as an effective way of developing skills to solve real-life problems. Preservice teachers state that it contributes to both their development and their studen s' development. Also, as they think that they deal with the problems linearly and their solution may be unique, they refer that they have developed multi-faceted perspectives and solutions through these activities. Henceforward, they express that they can overcome everything in real life by making more realistic critical thinking, not the activities or materials they are doing. It was found that individuals developed self-criticism about what they can and cannot do thanks to STEM activities and, most importantly, they increased their self-confidence in what they can do. In this sense, STEM is thought to provide knowledge, skills, attitudes and values by pre-service teachers (Wendell vd., 2010). The pre-service teachers stated that STEM will develop many high-level 21 st century skills such as problem-solving and critical thinking. It was seen that participants had positive thoughts in terms of developing STEM-related skills. STEM education improved their skills to look at problems and produce multiple solutions. It was observed that there were several studies in the literature that individuals improved their knowledge, skills and abilities, and this has the feature to support our research (Riskowski vd., 2009: 192; Park vd., 2011: 87; Kim \& Choi, 2012: 222; Kwon vd., 2012: 82; Cotabish vd., 2013; Sahin vd., 2014: 318; Y1ldrım, 2016). In this scope, considering the expressions of the preservice teachers, it is concluded that the STEM education is also effective in problem-solving and decision-making skills (Dym vd., 2002: 238; Denson 2011; Jonassen, 2011; Bozkurt, 2014). It was determined that the pre-service teachers developed their self-confidence in this sense during the STEM education. Also, it was found that they had the tendency to be motivated, to have a desire to succeed and hope to do so, and try to do what is necessary. It was 
determined that they can continuously develop ideas, to think in multiple ways, to make judgments, to produce alternative solutions, to try out solutions and to provide field competence while providing them. It was concluded that the pre-service teachers, who have been provided with STEM education, are willing to apply STEM in their lessons (Capobianco, 2011: 255; Capobianco 2013). In this scope, it is very significant, in terms of science education, for the pre-service science teachers to be willing and uncontested in creating teaching environments based on STEM, and their positive expressions in this regard. Although the implementation of STEM education requires time, it increases the level of interest in the course by contributing to various top-level skills. In the interviews carried out after the STEM activities, the pre-service teachers stated that they realised permanent and complete learning in the fun process that improves their creativity as well as contributing to their problem-solving skills. The fact that the pre-service teachers have positive thoughts is significant in terms of raising qualified individuals as well as practices that allow meaningful learning in science. The pre-service teachers stated that STEM will be effective in every subject since it includes fun activities for children, thereby it will improve their self-confidence and self-efficacy.It is stated that there will be an increase in the motivation to learn without the age limit, creative thoughts such as developing feelings of interest and imagination. The pre-service teachers stated that it contributes to scientific process skills. Similarly, it is suggested in other researches that it is effective in developing the scientific process skills (Sullivan, 2008: 389; Clarke, 2010; Bozkurt, 2014). The importance of the functionality of STEM education to develop scientific process skills is also emphasized in this sense. This case is thought to be related to the integration of STEM with scientific process skills. It is stated that STEM contributes to the questioning skill that is considered important by the pre-service teachers in terms of problem-solving (AslanYolcu, 2014). The questioning skill that should be present not only in teachers butin all individuals, is accepted as the basis of problem-solving. STEM is not seen as a result that students try to apply traditionally structured scientific knowledge focusing on well-defined problems to a real-world problem. In contrast, it is at the heart of the individual experiences. It was observed that the pre-service teachers thought that they were in the behaviour of cooperating with their friends, exchanging information, listening to their friends' ideas, respecting, acting, and sharing during the STEM education. In this scope, STEM should have the features to develop primarily the highlevel skills of teachers considering that it is a way of developing individuals, in terms of shedding light on generations (Robinson vd., 2007: 22; Stauffer \& McMullin, 2009; Crawford vd., 2011). Considering that teachers teach as the way they learn, pre-service teachers should be aware of the importance of problem-solving skills and scientific process skills related to the quality of education, the importance of learning and learning styles, and understand that they show individual differences, have knowledge and skills when they become teachers. While developing this knowledge and skills, it is very significant for academicians in education faculties to be sensitive in terms of leaving their characteristics as much as possible and developing objective attitudes and behaviours. Although this research demonstrates harmony with other researches, it will be beneficial to carry out similar studies within-service teachers or pre-service teachers in other education faculties to reveal the situation clearly and accurately in our country. In conclusion, investigating the effect of STEM education on pre-service science teachers' problem-solving skills, increasing the positive views and the quality of science education and developing new approaches in education are significant. For this reason, taking the opinions of pre-service teachers, effective implementation of STEM, and bringing knowledge and skills to education by educating qualified individuals will be a useful step for our country as well as shedding light on science education.

Keywords: Science Education, Teacher Education, Science Teacher Candidates, Problem Solving Skills, STEM

Öz: Bu araştırmanın amacı; STEM eğitiminin fen bilgisi öğretmen adaylarının problem çözme becerilerine etkisini incelemektir. Bu amaç doğrultusunda Erzincan Binali Yıldırım Üniversitesi Eğitim Fakültesi Fen Bilgisi Öğretmenliği Bölümünün 3. sınıflarında okuyan 30 öğretmen adayı ile STEM uygulamalarına yönelik dersler ve görüşmeler yapılmıştır. Karma yöntemin kullanıldığı çalışmada; problem çözme becerilerini nicel verilerle ölçebilmek amaciyla problem çözme ölçeği tek grup ön test-son test olarak uygulanmıştır. Nitel verileri elde edebilmek için ise odak grup görüş̧mesi tekniği uygulanmıştır. Nitel veriler nicel verileri destekleyici niteliktedir. Odak grup görüşmesi sırasında araştırmacı tarafından nicel verilerinin daha detaylı araştırılmasına katkı sağlayabilecek açık uçlu sorular kullanılmıştır. Sorular bu amaç doğrultusunda kullanılan ölçeğin alt boyutlarına paralel olacak şekilde hazırlanmıştır ve uzman görüşü alınarak son hal verilmiştir. Araştırmada STEM eğitiminin öğretmen adaylarının problem çözme becerilerinin gelişimine olumlu katkısı olduğu tespit edilmiştir. Öğretmen adaylarının problem çözme becerilerinin gelişiminde; STEM eğitimi esnasında karşılaşmış oldukları problemleri çözmek durumunda kalmalarından kaynaklandığını düşünmüş oldukları saptanmıştır. Ayrıca STEM Eğitiminin problem çözme becerilerinin temelini oluşturan bazı bireysel özelliklerine de etkisinin olduğunu düşündükleri 
saptanmıştır. Bunlar; problem çözmeye karşı istekli, sabırlı ve cesaretli olma, sorumluluk alma, karar verme, fikirlerini zit düşüncede olan kişilere bile özgürce ifade etme ve gerektiğinde savunma olarak belirtmişlerdir. Bununla birlikte STEM eğitimi ile problem çözme gibi birçok üst düzey becerinin geliştirilebileceği görüşüne sahip oldukları tespit edilmiştir. Ayrıca STEM'in çok yönlü yapısı ile bireylerde çok çeşitli yeni gelişmelere katkıda bulunduğu belirtilmektedir. Hem kendi gelişimlerine hem de ders verecekleri öğrencilere katk1 sağlayacağını düşünmektedirler. STEM; bireylere disiplinlerarası düşünme yetisi kazandırarak, işbirliği içinde çalışmada deneyimler sunarken, temelde yaşama dair problemlere çözüm bulmalarına temel oluşturmakta olduğu için STEM'in gerçek yaşamdaki problemlere çözüm üretmede ve çok yönlü çözüm yollarını keşfetme ve geliştirmede etkin bir yöntem olduğunu vurgulamışlardır.

Anahtar Kelimeler: Fen Eğitimi, Öğretmen Eğitimi, Fen Bilgisi Öğretmen Adayları, Problem Çözme Becerileri, STEM

\section{Giriş}

STEM ana temasında bulunan dört disiplini, disiplinler arası bir bakışla öğretmenin yanı sıra bütün disiplinleri bir arada bulunduran farklı alanları simgelemektedir (Yıldırım \& Altun, 2015). Disiplinler arası kavramı, her birinin birbirinden farklı ancak birbiriyle ilişkili olmasıyla günlük yaşam problemlerinin çok sayıda doğru cevabı olduğuna işaret etmektedir (Perkins, 1994). Bireyler zihinsel potansiyellerini disiplinler arası ilişkilerini kurarak yaşamlarındaki problem durumlarını tecrübe ederek çözmeye çalı̧̧acaklardır. Bu durum özellikle daima gelişen ve değişen çağa adapte olma becerileri geliştirmelerine yardımcı olacaktır ve sorunlarına yaratıcı, eleştirel bakış açısı ile bakma niteliği kazanmalarını sağlayacaktır. Bireyler problemlerini; farklı disiplinlerin farklı yönlerini birbiri ile ilişkilendirerek çözebilme yeteneği kazanacaktır (Martinello, 2000). STEM; nitelikli bilgi ve becerilerle araştıran, sorgulayan hayatımızdaki problemlere yaratıcı, yenilikçi ve eleştirel çözümlerle yaklaşabilen hür düşünceli bireylerin yetiştirilmesinı amaçlamaktadır. Bu durum her alanda nitelikli bireylerin yetişmesi ve böylece ülkelerin sahip olduğu insan ve beyin gücü potansiyelinin artmasını sağlayacaktır (Wells, 2008). Literatür incelendiğinde bu önemin farkında olan ülkelerin STEM'e katkıda bulundukları ve öncelik verdikleri görülmüştür (Langdon vd., 2011). Çünkü STEM; bireylerin uyum ve gelişimlerinin olabilmesi, kendilerini farklı donanımlarla yetiştirmesine dayanmaktadır (Çınar vd., 2016). Günümüz donanımlarını STEM bilinci ve aracılığıyla geliştirmeleriyle önce fertlersonrasında kuşaklar ülke geleceğini şekillendireceklerdir (Figliano, 2007). Yaşadığımız yüzyılın görünen gerçek endişeleriyle baş edebilmek çeşitli etkenleri de göz önüne alarak mevcut eğitimde köklü değişikliklerin yapılmasını kaçınılmaz kılmaktadır. Eğitim süreçleri bireylerin kendilerine katkı sağlayan başarı ve mutluluğa ulaşmada en etkin yol olarak varsayılmaktadır. Üst düzey düşünme becerilerinin gelişimi bu süreçlerden geçmektedir (Kalayc1, 2001). Bu doğrultuda bireyler nitelik kazanarak ülkelerini kalkındıracak güce ulaşabileceklerdir. Düşünmelerini etkili ifade edebilen ve uygulayabilenler yaşamları boyunca karşılarına çıkacak durumlara problem çözme becerileriyle çözüm üretebileceklerdir. Eğitim sistem ve süreçlerinin ana amacı, mevcut bilgi ve becerileri tekrarlamaktan ziyade sağlıklı ve nitelikli bilgiye ulaşmaya müteveccihmaharetlerini edindirmelidir. Bu edinim üst seviye zihinsel becerilerin desteğiyle mümkündür. $\mathrm{Bu}$ üst düzey beceriler bireylere yaşamlarını entegre etme ve uygulamalarıyla hayat boyu çerçevede kazandırılmalıdır. Fen bilimleri bu becerilerin kazandırılmasında önemli disiplinlerden biridir (Tatar \& Kuru, 2006).

Bireylerin yaşam boyu karşılaştığı ya da karşılaşacağı bilgi ve tecrübelerden faydalanarak yanıta ulaşacağ durumlar problemlerdir (Olkun \& Toluk, 2001). Zihinsel süreçleri barındıran ve aniden karşılaşılan durumlardır. Sonuca götüren bu yolda çözüme kavuşturmaya engel durumların kaldırılmasını gerektirmektedir. Bu bakımdan bireylerin başka bireylerden yardım almayı, problemi başkalarının çözmesini beklemek yerine öz çabasını ortaya koyması, bazı durumlarda da riskleri göze alması gerekmektedir. Böylelikle kendini ifade edebilen özgüvenli bireyler görülebilecektir (Bingham, 2004). Problemlere çok yönlü bakabilenlerin onların üstesinden kolaylıkla geldiği gerçektir. Çok farklı problemler yaşam boyu karşımıza çıkmakta olacağından çok yönlü bakabilmek önem arz etmektedir. 
Problemlerin bu göreceli durumu kimi bireyler için sorun olarak görülmekte kimi bireyler içinse herhangi bir sorunu teşkil etmemektedir. Sorun olarak algilayanlar çoğu zaman tecrübelerinden faydalanmakta ve bazen çözüme kavuşturmakta başarısız olmaktadırlar (Cüceloğlu, 2003: 23). Bu noktada problem çözme becerisi önem kazanarak bu becerideki süreçler; bilişsel, duyusal ve sosyal taraflarına göre sorunların sağlıklı algılanmasını, buna yönelik çözümlerin bulunmasını içermektedir. Problemlerin göreceliliği, çözümlerinin de göreceliliğini beraberinde getirmektedir. Bu kapsamda da çeşitli etkinlikler, bireylerin nasıl karar alacaklarından nasıl hedeflerine ulaşacaklarına dair yardım sağlamaktadır (Dinçer, 1995). Çocukların geleceğin ebeveynleri de olduğu bilinciyle öz gelişimleri gereği hayat sorunlarına çare üretmeleri değerli bulunmaktadır. Tüm bilgiler ışığında erken yaş üst düzey becerilerinin gerekliliği tüm eğitim seviyelerindeki çocuklara öğretilmesi gereken temel ihtiyaçlardandır (Çepni, 2005: 85). Eğitim bütün kademelerinde bireylere düşünme becerilerini en etkin, kalıcı ve kestirme olarak meraktan başlayarak beyin firtınalarıyla tartışmalarla derin düşünme alışverişlerinde yaratıcılığa güdüleyerek düşünceler arası bağlarla sorgulamaya ve böylelikle gerçek yaşamlarına katk1 sağlayacaktır (Carr, 1990: 3). Bu bireyler çözüm bulmada son derece nitelikli, pozitif benlikli, iletişimde girişken ve akademik bakımdan başarılı algı ve davranışları sergileyecektir (Şahin vd., 1993). Bahsedilen bireyleri yetiştiren ya da yetiştirecek öğretmenlere ise her zaman gerek duyulacaktır. $\mathrm{Bu}$ doğrultuda bazı yetilerin gelişmesi bakımından öğretmenlerimizin niteliği de arttırılmalıdır (Willard- Holt \& Bottomley, 2000: 81; Loughran, 2002: 41). Benzer olarak öğrenen bireylerden önce öğreten bireylere donanım kazandırılmasının gerekliliği belirtilmiştir (Wilks, 1995). Ekspoze optimum öğretmenin tanımını; adaletli, samimi, sevecen, sempatik, neşeli, aktüel, iş disiplinli, mesleki bilgiye hakim olmasıyla sınıfta hakim olan, bireylerin duygu düşüncelerini önemseyen, isteklendiren, çok sayıda örneklerle ifadeler kullanan, sevdiren, yol gösteren, rehber, arkadaş, içimizden biri nitelemeleriyle belirtmişlerdir (Senemoğlu 2001: 210; Çalışkan vd., 2013: 580). Öğrenenleri, öğretenin kanaatindeki tüm tasarrufları tesir altına almakta ve anlatılan konulardan çok onu yorumlaması ile yorumlama biçimi dikkat çekmektedir (Varış, 1998). O yüzden aldıkları eğitimden, nasıl öğretmen olunduğu ya da olunacağı, öğretmenlerimizin kendi öğrencilik dönemlerindeki gelişimleriyle ilgili bulunmaktadır (Can, 1987: 165).

Bilimsel ve teknolojik gelişmeler eğitimi de etkilemektedir. Eğitimde yaşanan değişimler sonucu da öğrencilerden 21.yy becerilerini kazanmış ve geliştirmiş bir şekilde okullardan mezun olmaları beklenmektedir. Öğrencilere bu becerileri kazandıracak olan öğretmenlerdir. STEM eğitimi de bu becerileri kazandırmanın etkili yollarından biridir. Bu bağlamda, araştırmada farklı kademelerde ve farklı branşlarda görev yapan STEM eğitimi almış öğretmenlerin STEM farkındalıklarının problem çözme becerilerini ve davranışlarının öğrencilerin yaratıcı düşünme becerisinin gelişimine katkısının yordanması amaçlanmıştır (Acar, 2020: 83). Eğitim- öğretim sürecinde bu yaklaşımı uygulayacak olanlar ise öğretmenlerdir. STEM eğitiminin en önemli amaçlarından biri olan 21. yy becerileri, Milli Eğitim Bakanlığı (2018a; 2018b) tarafından da öğretim programlarında kazandırılacak beceriler arasında yer almaktadır. Bu bağlamda öğretim programlarında da sıklıkla vurgulanan problem çözme becerisi ve yaratıcılık becerilerinin kazandırılmasında öğretmenlere büyük görev düşmektedir (Acar, 2020). Öğretmen öğrencileri için rol modeldir. Öğretmenin problem çözme becerisi, sınıf ortamında karşı karşıya kaldığı problemleri çözerken nasıl bir yol izlediği, nasıl davrandığı öğrenciler açısından önemlidir. Çünkü bu davranışlar öğretmenin problem çözme becerisinin bir göstergesidir. Öğretmenin problem çözme becerisi sınıf atmosferini doğrudan etkiler. Dolayısıyla, öğrencilere problem çözme becerisi kazandırılması hedeflenirken, öğretmenlerin sahip olduğu problem çözme becerisi de önemlidir. Alanyazın incelendiğinde, problem çözme becerisi yüksek olan öğretmenlerin bu becerilerini eğitim sürecinde daha çok kullanabilecekleri ve bunun sonucunda öğrencilerinin de problem çözme becerilerinin gelişebileceği ifade edilmektedir (Ceylan, 2014; Sarı \& Bozgeyikli, 2003: 199). Problem çözme süreci yaratıcı düşünmeyi de gerektirir. Problemi çözmek için bir arayışa giren, zorlanan birey yaratıcı çözümler bulur. Miller ve Nunn (2001), problem çözme becerisine sahip bireylerin yaratıcı, bağımsız düşünen ve kendine güvenen bireyler olduklarını ifade etmektedirler. 
Literatür incelendiğinde; öğrencilerin STEM becerilerini (Lou, vd.,2011), STEM eğitiminin öğrencilerin STEM becerilerine (Scott, 2012; Tseng, vd., 2013: 87), öğrencilerin başarılarına (Öner \& Capraro, 2016: 14; Kırgız \& Koyuncu, 2016: 64; Yılmaz vd., 2017: 112), öz yeterliliklerine (Boyle, 2019), kalıcılığına (Yıldırım, 2016), öğrenme süreçlerine (Guzey vd., 2016: 558; Lie vd., 2019: 113), kariyer seçimlerine (Bingolbali vd., 2007: 773; Bilekyiğit, 2018; Karc1, 2018), zihinsel süreç becerilerine etkisini (Akins ve Burghardt, 2006; Sari vd., 2019) inceleyen çalışmalar bulunmaktadır. Fen Bilgisi Öğretmen Adayları ile ilgili literatür incelendiğinde ise; STEM Eğitiminin öğretmen adaylarının bilim doğası inançlarına ve yapılandırmacı yaklaşıma yönelik tutumları (Yıldırım vd.,2017), bilimsel süreç becerilerine (Gökbayrak \& Karışan, 2017), STEM eğitimi ve mühendislik uygulamalarının öğrencilerin başarıları (Yıldırım \& Altun, 2015: 36), fen bilgisi öğretmen adaylarının STEM Eğitimine yönelik görüşlerine (Yıldırım, 2016), uygulama becerilerine (Bozkurt Altan vd., 2016; Eroğlu ve Bektaş, 2016: 228; Madden vd., 2016) ve entegrasyon becerilerinin (Wang, 2012; Kelley \& Knowles, 2016) araştırıldığ çalışmalara rastlanmaktadır. STEM Eğitiminin bireylerin problem çözme beceri üzerine etkisi incelendiğinde; STEM Eğitiminin öğrencilerin problem çözme becerilerini geliştirdiği tespit edilmiştir (Cho \& Lee, 2013). Dewaters ve Powers (2006: 9) fen bilimleri dersini STEM Eğitimi temelli olarak yürütmüş ve öğrenciler üzerindeki etkisini araştırmıştır. Çalışmanın sonucunda öğrencilerin problem çözme becerileriniarttırdığg 1 ve fen bilimleri dersine karşı tutumlarının olumlu yönde değiştiği tespit edilmiştir. Acar (2020:79) öğretmenler üzerinde yaptığı çalışma da STEM farkındalıklarının problem çözme becerilerinin anlamlı bir yordayıcısı olduğu tespit edilmiştir. Literatürde STEM Eğitiminin fen bilgisi öğretmen adaylarının problem çözme becerileri üzerine etkisi ile ilgili çalışmaya rastlanamamıştır. Problem çözme becerisi gelişmiş bir öğretmenin sınıf içinde karşılaşmış olduğu bir problemi daha hızlı ve etkili bir biçimde çözebileceği ve bu beceriyi öğrencilerine kazandırma konusunda deneyimli ve istekli olacaktır. Bu amaç doğrultusunda çalışma da STEM Eğitiminin Fen Bilgisi Öğretmen Adaylarının problem çözme becerileri üzerine etkisi araştırılması amaçlanmıştır.

\section{Yöntem}

Çalışmada, 'STEM eğitiminin öğretmen adaylarının problem çözme becerilerine etkisi'nin araştırılması amaçlanmıştır. Erzincan Üniversitesi Fen Bilgisi Öğretmenliği Bölümü 3. Sınıf’ larındaki öğretmen adayları evren ve seçkisiz atama barındırmayan uyumlu örnekleme tekniği ile örneklem seçilmiştir. Çalışmaya 30 Fen Bilgisi Öğretmen Adayı katılmıştır. STEM teorik ve uygulama eğitimleri gruba bir haftada 4 saat olarak 14 hafta boyunca verilmiştir. Eğitimler; temel materyaller, lego ve tipler, robotik ve de kodlamalar yoluyla adayların öz gelişimlerini destekler nitelikte verilmiş, kendi derslerinde uygulayıp derslerine uyarlayabilecekleri çerçevede birçok etkinlikle de zenginleştirilmiştir.

Çalışmada karma yöntem kullanılmıştır. Karma yöntem nitel ve nicel araştırma yöntemlerinin belirli bir düzen ve mantık çerçevesinde birlikte kullanılması işidir (Büyüköztürk vd,. 2016). Karma yöntemde veriler nicellik, nitellik ya da baskınlıklarına göre kategorilendirilmekte ve adlandırılmaktadır (Johnson vd., 2007: 115). Kategorilendime; açıklayıcı, çeşitleyici, keşfedici karma teknikler olarak belirtilmiştir (Creswell, 2002). Açılayıcı desen; nicelliğin hâkim durumlarında [NIC+nit], veriler toplanır, çözümlenir sonrasında birleştirilirek yorumlanmaktadır (Creswell ve PlanoClark, 2007). Creswell' in (2002)'e göre aşağıdaki soruların yanıtlanması araştırmanın ne şekilde yönlendirileceği bakımından önemli bulunmaktadır. 1. Nitel ve nicel veri toplama yöntemlerinin öncelik ya da ağırlığ nedir? Çalışmada, nicel yöntemlere nitel yöntemlerden daha fazla önem verilmiştir. 2. Nitel ve nicel verileri toplama sırası nasıldır? Çalışmanın önce nicel sonra nitel verileri toplanmıştır. 3. Veriler nasıl analiz edilecektir? Çalışmanın nicel ve nitel verileri ayrı ayrı analiz edilecektir. 4. Araştırmanın hangi aşamasında veriler birleştirilmektedir? Tüm veriler çalışmanın bulgularını yorumlama aşamalarında bir araya getirilerek iliş̧kilendirilmiştir. Açıklayıcı desen, çalışmanın gereği ve nicelliğin baskın oluşu dolayısıyla tercih edilmiştir. Nicel bilgilerin toplanıp, analiziyle çıkan sonuca destek ve tamamlama niteliğinde nitel bilgilerin toplanıp, analizi yapılmış ve sentez kurulmuştur. Nicel verilerin eldesinde desen ve düzen olarak deneysel çalışma çeşitlerinden zayıf deneysel ve tek gruba yönelik öntest- son 
test uygulanmıştır. Bu desen; herhangi yeni program, müfredat etkisini irdeleme veya alakalı öneriler getirmeyi sağlaması sebepleriyle ihtiyaca uygun bulunarak seçilmiştir (Büyüköztürk vd., 2016). Zayıf desen seçimiyle tek gruba yapılan deneysel uygulamanın etkisi çalışma kapsamında incelenmeye çalışılmıştır. Gruba etkide bulunmadan önce ön testler bulunduktan yani STEM Eğitimi verildikten sonra son testler yapılmıştır. Ölçme aracı niteliğindeki testler birbirinin aynıdır ve aynı şekilde uygulanmıştır. Veri toplamada 'Problem Çözme Becerileri Ölçeği' kullanılmıştır. Problem Çözme Becerileri Ölçeği; 32 maddeden oluşan 6'lı likert tipi bir ölçektir (Taylan, 1990). Ölçeğin bu örneklem için cronbrach alfa sayısı $=0.87$ olarak tespit edilmiştir. Nicel verilerin sonuçları SPSS paket programı yardımı ile analiz edilerek sonrasında yorumlamaları yapılmıştır. Uygulamalardan sonra nicel verilerden elde edilen sonuçların nedenlerini daha detaylı tespit edebilmek amacıyla adaylarla odak grup görüşmesi yapılmıştır. Odak gurup görüşmesinde kullanılan sorular nicel verileri toplamak için kullanılan Problem Çözme Ölçeği'nin alt boyutlarına paralel olarak hazırlanmıştır. Ölçek 3 alt boyuttan oluşmaktadır. Bunlar; kişinin yeni problemleri çözme yeteneğine olan inancını ifade eden "problem çözme güveni" alt boyutudur. Öğretmen adaylarının STEM Etkinliklerini gerçekleştirme esnasında karşılaşmış oldukları problemlere karşı tutumlarını ortaya koyabilmek amacıyla "Bu etkinlikleri yaparken çok sayıda problemle karşılaştınız mı? Karşılaştığınız problemi nasıl çözdünüz ve neler hissettiniz?” sorusu sorulmuştur. "Yaklaşım- Kaçınma" alt boyutu: Bireyin gelecekte başvurmak için ilk problem çözme çabalarını yeniden gözden geçirmesi ve değişik alternatif çözümler için aktif bir biçimde araştırma yapma çabasını ifade etmektedir. Öğretmen adaylarının STEM Etkinlikleri esnasında problemleri çözmek için kullanmış oldukları çözüm yollarını ve çabalarını ortaya koymak amacıyla "Herhangi bir etkinliği yaparken sonuca ulaşamadığınızda neler hissettiniz? Neden sonuca ulaşamadığınızı düşündünüz mü? Bir çözüm yolu üretmeye çalıştınız mı? Nasıl?" sorusu sorulmuştır. Kişisel kontrol alt boyutu: Problemli durumlarda kişisel kontrolünü sürdürme yeteneğini ifade etmektedir. "STEM Etkinlikleri esnasında karşılaştı̆̆ınız bir problemle sonuca ulaşamayacağınızı bilseniz bile yine de yeni yollar aradınız mı, bulmaya çalıştınız mı? Neden?” Ayrıca öğretmen adaylarının STEM Etkinliklerinin problem çözme becerilerine etkisinin olup olmadığı konusunda ne düşündüklerini tespit edebilmek amacıyla "Yapmış olduğunuz STEM etkinliklerinden sonra karşınıza çıkan bir probleme yönelik tutumunuzda ve düşüncelerinizde ne gibi değişiklikler oldu" sorusu sorulmuştur.

Nitel araştırma yöntemlerinde geçerliliği sağlamak için; çok sayıda araştırmacı, çoklu veri kaynakları veya bulguları doğrulamak için çoklu yöntemler kullanmak, elde edilen veri kaynaklarını tekrar kontrol ettirmek önemlidir. Ayrıca olguyu uzun süreli veya tekrarlı gözlemlere tabii tutmak, bulgularda ortaya çıkan yorumların meslektaşlar tarafından değerlendirilmesi, çalışmanın kuramsal aşamasından bulguların yazım aşamasına kadar tüm aşamalarda katılımcıların yer alması hususlarına özen gösterilmelidir (Merriam, 1998). Veriler üniversite bünyesinde açılmış olan STEM- RobotikKodlama dersi bünyesinde toplanmış olup etkinlikler 14 hafta boyunca gerçekleştirilmiştir ve öğretmen adaylarının herbirinin sürece katılımı konusunda hassasiyet gösterilmiştir. Etkinliklerin gerçekleştirilmesi süreci ve verilerin toplanma süreci 4 yüksek lisans öğrencisi ve 1 akademisyen iş birliğinde gerçekleştirilmiştir. Verilerin çeşitlendirilmesi için öğretici ve veli görüşleri alınmamış olup sadece nicel veriler ile birbirine uyumuna bakılmıştır. Nicel ölçeğin ve odak gurup görüşmesi için kullanılan soruların çalışmanın amacına ve örneklem gurubuna uygun olup olmadığı hususunda eğitim alanında uzman 3 akademisyenin görüşleri alınmıştır. Odak gurup görüşmesi 5'erli gruplar halinde gerçekleştirilmiştir ve ses kayıt cihazı ile kayıt altına alınmıştır. Daha sonra ses kayıtları yazılı hale getirilerek içerik analizine tabii tutulmuştur. Odak gurup raporlarında sayısal verilerden (yüzdeliklerden) ziyade kişilerin ve grupların derin algıdaki bireysel tutumları ve grup davranışı olarak nihai kararlarına ait niteliksel yorum ve ifadeler yer alır. Bundan dolayı sonuçlar daha açımlayıcı şekilde verilmelidir, nicelleştirilmesine gerek yoktur yani yüzde, frekans ya da istatistiksel testlere ya da tablolara gerek yoktur (Edmunds, 2000).

Bir başka deyişle çözümlemeler nicel çalışmalara göre daha az yapılandırılmış, daha çok açımlayıcıdır Sayısal veriden çok, bireysel düşüncelerin farklılıklarının nasıl verildiği önemlidir. Ayrıca, araştırmacının öne sürdüğünün aksine, ortaya çıkan farklılıkları sunmak bütün nitel araştırmalarda 
olduğu gibi, burada da çok önemlidir (Kitzinger, 1995: 300). Verilerin analizinde içerik analizi en uygun yöntemdir (Kitzinger, 1994:107). Veri analizinde en iyi yol, kayıt sırasında ya da sonrasında çözümleme yapılırken, belli başlıklar altında anahtar temaları belirlemektir. Kayıt sırasında alınan kısa notlar bile daha sonra yapılacak anlizler için oldukça yararlıdır. Odak grup görüşmesinin raporlaştırılmasında önemli olan sayılar değil katılımcıların ne söylediğidir (Creswell, 2012). Raporda genel olarak temalara göre belirlenen algılar yer almalıdır. Araştırmacılar, analiz yaparken ve raporlaştırırken konuşma dilinin olduğu gibi kalmasına dikkat etmelidir

\section{Sürec}

Adaylar için STEM ve eğitimi adına tüm olasılık durumları düşünülerek literatür irdelenmiştir. Eğitimlerin gerçekleştirileceği ortam, beklentiler, etkileşimler, izlenecek yol, teorik ve pratik boyutları irdelenmiş, düşünülmüştür. Nihayetinde bütünsellik benimsenmiş, pratiği içselleştirmelerine karar verilmiştir. Bununla birlikte özel tercih edilen durumlar (uygulamalar, etkinlikler) araştırmacının deneyimlemeleriyle kriterleştirilmiştir. Seçimlerde çoğunlukla içerik bakımından STEM'in bulunma oranı düşünülerek bireylerin alana ilişkin bilgileriyle sıra dışı enteresan tasarımlar bulma coşkularını destekler olması, öz bilgi, deneyim, tecrübeleriyle birçok sorunu çözebilecekleri, keşfederek üretecekleri, benliklerini ve mesleki bakımdan gelişimlerini sağlayabilecekleri düşüncesiyle iş yaşamlarında öğretme atmosferlerinde uygulayabilecekleri seviyede hazırlık yapılmıştır. Sorunlarına duyarlı basit ucuz malzemeler, web 2.0 araçları, robotik, lego, kodlama gibi uyumlarıyla STEM'in her çeşit uygulama biçimleri gerçekleştirilmiştir. Adayların rastgele kişi, kuruluştan konuya ilişkin eğitim alıp almadıklarının denetimi yapılmış ve ilintili hiçbir öğrenimde bulunmadıkları belirlenmiştir. Araştırmada oluşacak etkililik bakımından net verilerin yalnızca bir kaynaktan ortaya konacağı görülmektedir. STEM eğitimin teori ve pratiği haftada 4 defadan 14 hafta olarak lisans seviyesindeki öğretmen adaylarına problem çözme durumlarını ölçen ön ve son uygulamalarıyla yapılmıştır.

\section{Bulgular ve Yorum}

\section{Nicel Verilerin Analizi}

Bilinen istatistiksel yazılım SPSS 22,0'dan yararlanılmıştır. Bilgilerin çözümlemesinde belirsiz olarak istatistikî prosedürün kararına erişim için bilgilerin normal dağılım sağlayıp sağlamadığının tayini açısından bütün ölçümlerin histogram grafikleriyle çarpıklık katsayısı göz önüne alınarak Kolmogorov-Smirnov (K-S) testiyle karşıllklarının normallik farazisinin makulluğu denetlenmiştir. Meydana gelen grafiklerle değerler ölçümlerin normal dağılıma işaret etmektedir. $\mathrm{Bu}$ istikamette araştırmanın çözgüsü olan öğretmen adaylarının problem çözme yeteneklerine tesirinin irdelenmesi münasebetiyle ön test ve son test mukayesesinin inşası açısından ilişkili örneklemler (paired) $t$ testinden faydalanılmıştır.

\section{Nitel Verilerin Analizi}

Araştırmanın gayesine haiz oluşu ile nitel analiz tekniklerinde çoğu kez karşılaşılan bir yöntem olması nedeniyle içerik analizi tercih sebebidir. İçerik analizitekniğinde kazanılan bilgilerin toplanarak izahı için gerekli olgu ve illiyetle gizli hakikatlere erişmeyi amaçlamaktadır. Bu yöntemle araştırmacı aracılığıyla limitli kodlar meydana getirilerek ilişkin kategoriler oluşturulmaktadır. Sonrasında kategorilerin temel gerçekliği açığa çıkartan izahların bulunması için çaba sarfedilmektedir (Yıldırım ve Şimşek, 2008). Analiz, odak gruba uyumlu kullanılmıştır. İçerik analiziyle nitel veriler dört etapta çözümlenmektedir; bilgilerin kodlanması, konuların bulunması, kodların ve konuların tertibi, semptomların tanımı ve yorum evrelerini içermektedir.

Bilgilerin kodlanması; evresinde araştırmacı, ulaştı̆ğ verileri inceler, mantıklı kısımlara ayırırak kısımların kavramsal olarak içerdiği manasının bulunulması için çabalanmaktadır. Burada çabalanan herhangi bir sözcük olabildiği gibi cümle hatta paragraf ya da bundan fazlasını çağrıştıran bilgileri bulundurmaktadır. Kendi içinde manalı aksamlar da araştırmacı aracılığıyla kod haline getirilmektedir. $\mathrm{Bu}$ süreç araştırmacının çokça okuyup, dinlemesini böylelikle meydana gelen kodlar üstünde 
yineleyerek çalışma yapmasını gerektirmektedir. Bilgilerin kapsamıyla yoğunluğu gereğince ortaya konan kodların miktarı değişim göstermektedir. Odak grup görüşmesinin bildirgesinde değerli olan sayılar yerine katkıda bulunanların söylemleridir (Çokluk vd., 2011:102). Mülakatta alınan ses kayıtları, yazıya dökülmüsşür. Çıkarılan bilgilere dayanak sağlayan odak grup mülakatına yönelik kayıtların kategorilendirilmesiyle içerik analizi yapılmıştır. Çalışmanın kavramsal sınırları düşünülerek veri analizine ilişkin gerekli altyapı hazırlanmıştır. Hazırlanan altyapı yönünde öğretmen adaylarının söylemlerinde vurguladıkları araştırma doğrultusuna ilişkin sözcükler, tümceler veya paragraflar kod ve kategoriler durumuna dönüştürülmüştür. Açık uçlu suallerin temasına yönelik odak grup görüşmeleriyle kazanımların analizinde içerik analizi metodundan faydalanılarak kodlar oluşturulmuştur. Emsalliklerine göre kodlar kategorilendirilerek tüm kategoriler alakalandırılarak adları konulmuştur. Kodlar ile kategoriler; araştırmanın teorik biçimi, açık uçlu sualler katılanların belirttiği yanıtlar doğrultusunda oluşturulmuştur. Öğretmen adaylarının her birinin verileri yinelenerek dinlenmiş ve ayrı kodlar, kategoriler arasındaki ilişkilerin irdelenmesine yönelik çaba gösterilmiştir. Süreçte araştırmanın çözümlenmesinde bütün veri toplama araçlarının itimadı açısından ayrı araştırmacılarla konrolü yapılmıştır.

'STEM' in fen bilgisi öğretenbireylerinsorun çözme yeteneklerine etkisi'nin irdelenmesi gayesiyle yapılan bu araştırmada; nicel, nitel veriler elde edilmiştir. Çalışmanın yukarıda belirtilen problem cümlesi olarak 'anlamlı fark var mıdır?' ş̧eklinde sorulmaktadır. Tek gruplu çalışmanın problem çözme yeteneklerine ait ön, son testler biçiminde pairedsamples t testi sonuçları Tablo 1.'de belirtilmiştir.

Tablo 1: Problem Çözme Becerilerine İlişkin Paired Samples t Testi Sonuçları

\begin{tabular}{ccccccc}
\hline Problem Çözme & $\mathrm{N}$ & $\overline{\mathrm{x}}$ & $\mathrm{S}$ & $\mathrm{sd}$ & $\mathrm{t}$ & $\mathrm{p}$ \\
\hline Öntest & 30 & 136,8 & 14,81 & 29 & $-5,39$ &, $000^{*}$ \\
Sontest & 30 & 157,56 & 14,92 & & & \\
\hline $\mathrm{p}<0,05$ & & & & &
\end{tabular}

Problem çözme becerilerine ilişkin ortalamaları arasında bir fark olup olmadığını belirlemek için yapılan ilişkili örneklemler $\mathrm{t}$ testi sonucunda, eğitim öncesi yapılan problem çözme becerileri testi ortalaması ( $($ XÖntest $=136,8)$ ile eğitim sonrası problem çözme becerileri testi ortalaması ( XSontest $=157,56)$ arasında anlamlı bir fark görülmüştür. $[\mathrm{t}(29)=-5,39, \mathrm{p}<0,01]$. Test sonucu hesaplanan etki büyüklüğü $(\mathrm{d}=0,98)$ bu farkın yüksekdüzeyde olduğunu göstermektedir. Bu verilerinin analizinde herhangi bir istatistikselyönteme karar verebilmek için verilerin normal dağılım gösterip göstermediğinin belirlenmesi bakımından tüm ölçümlerin histogram grafiklerine ve çarpıklık katsayısına bakılarak Kolmogorov-Smirnov (K-S) testi ile değerlerin normallik varsayımına uygunluğu kontrol edilmiştir. Ortaya çıkan grafik ve değerler ölçümlerin normaldağılım gösterdiğini belirtmektedir.

Nitel veriler kapsamında öğretmen adayları tarafından geliştirilen kodlar belirlenmiştir. Kodlardan, birbirine yakın konuları kapsayanlar aynı konu başlığı altındatoplanarak kategoriler belirlenmiştir. Bu kodların birbirlerine benzer olma durumları göz önüne alınarak benzetme yöntemiyle kategoriler belirlenmiştir. Bu amaçla lisans öğrencilerinin STEM kavramına yönelik geliştirdikleri kodlar, bu kodların yer aldığı kategoriler tablolar halinde verilerek sonrasında örnek öğretmen adaylarının ifadelerine aşağıda yer verilmiştir.

“Bu etkinlikleri yaparken çok sayıda problemle karşılaştınız mı? Karşılaştı̆̆ınız problemi nasıl çözdünüz ve neler hissettiniz?" sorusuna göre öğretmen adaylarının verdikleri cevaplardan 6 kategori ve 34 kod oluşturulmuştur. 
Tablo 2: Katılımcıların Etkinliklerde Problemlerle Karşılaşıp Karşılaşmadıkları, Onları Nası1 Çözdükleri ve Neler Hissettikleri

\begin{tabular}{|c|c|}
\hline Kategori & Kod Ad1 \\
\hline \multirow{10}{*}{ Sosyal } & Dinleyici Olma \\
\hline & İnsanlar Arası İlişkiler \\
\hline & Bilgi-Fikir Alışverişi \\
\hline & Dayanışma-İşbirliği \\
\hline & Paylaşma \\
\hline & Sayg1 Duyma \\
\hline & Güven \\
\hline & Uzlaşmada Açıklık \\
\hline & Araştırmaya Güvenme \\
\hline & Deneme-Yanılma \\
\hline \multirow[t]{6}{*}{ Yöntem } & Tartışma \\
\hline & Yeni Denemelerde Israrcı Olma \\
\hline & Uzman Yardımı \\
\hline & İstekli Olma \\
\hline & Yeniliğe Açık Olma \\
\hline & Fikirlerini Özgürce Belirtme \\
\hline \multirow[t]{8}{*}{ Bireysel Özellikler } & Karar Verme \\
\hline & Sabırlı olma \\
\hline & Cesaretli Olma \\
\hline & Sorumluluk \\
\hline & Kendini İfade Etme Başarısı \\
\hline & Başarılı Olma Duygusu \\
\hline & Fikir Geliştirme \\
\hline & Çok Yönlü Düşünme \\
\hline \multirow[t]{4}{*}{ Duygu-Düşünce } & Motivasyon \\
\hline & Muhakeme ve Eleştirel Açıklık \\
\hline & Umut \\
\hline & Ortak Çözüm \\
\hline \multirow[t]{4}{*}{ Sonuçlandırma } & Uygulama \\
\hline & Alternatif Çözüm \\
\hline & Üretme \\
\hline & Bilgi Birikimi-Deneyim \\
\hline \multirow[t]{2}{*}{ Bireysel Yeterlilik } & Bilgi Yetersizliği \\
\hline & Alan Yeterliliği \\
\hline
\end{tabular}

Öğretmen adaylarının vermiş oldukları örnek cevaplar;

"Yok. Pek problemle karşılaşmadım çünkü bundan önce biz bunun eğitimini gördük. Ee tabi ki de bu kodlama esnasında ufak tefek sikıntılar vardl, onu da işte hocalarımızla çözdük..."

"Hayır...."

"Alan eksikliğinden kaynaklanan çok şeyle karşılaştık çünkü...alanımız çok eksik...."

"Kendimizden bir üst dönemlerimiz de vardl onlara gittik, birkaç arkadaşa sorduk nasıl yapabiliriz diye......kendi grup arkadaşlarımızla tartıştı....̈̈ğretmenden de tabi yardım aldık.....yüksek lisans ögrencilerimizde vardı onlara da sorduk ,.."

Öğretmen adaylarının hepsi etkinlikler esnasında problemlerle karşılaştıklarını belirtmişlerdir.

Tablo 2.de de görüldüğü gibi öğretmen adaylarının etkinlikler esnasında karşılaşmış oldukları problemleri deneme yanılma yoluyla çözmeye çalıştıkları, sorunlar hakkında tartışarak, araştırma yaparak, uzmanlardan yardım alarak, farklı yollar deneyerek çözmeye çalıştıklarını belirtmişlerdir. Ayrıca ortak çözüm üretme, üretikleri çözümleri uygulama esnasında zamanla birbirlerini dinlemeyi ve fikirlerine saygı duymayı, uzlaşmacı davranmayı öğrendiklerini vearkadaşları ile birlikte dayanışma ve işbirliği içinde bilgi ve fikir alışverişinde bulunarak çözmeye çalıştılarını belirtmişlerdir. Etkinliklerde 
karşılaşmış oldukları problemler sayesinde karar verme, sabırlı olma, motive olma, sorumluluk sahibi olma, kendini ifade etme cesareti gösterme, fikir geliştirme, sorunları çözme konusunda cesaretli olma, çok yönlü düşünme, muhakeme yapma ve eleştiriye açık olma becerilerinin geliştiğini belirtmişlerdir. Bu etkinliklerin çözüme ulaşması için istekli olma, yeniliğe açık olma, alan yeterliliği, deneyim ve bilgi yeterliliğine sahip olmanın gerektiğini belirtmişlerdir ve bunların bazılarının kendilerinde ve arkadaşlarında zaman zaman eksik olduğunu vurgulamışlardır.

"Herhangi bir etkinliği yaparken sonuca ulaşamadiğınızda neler hissettiniz? Neden sonuca ulaşamadiğınızı düşündü̈nüz mü? Bir çözüm yolu üretmeye çalıştınız mı? Nasıl?” sorusuna göre öğretmen adaylarının verdikleri cevaplardan 6 kategori ve 24 kod oluşturulmuştur.

Tablo 3: Katılımcıların etkinliklerde sonuca ulaşamadıklarındaki tutumu

\begin{tabular}{ll}
\hline Kategori & Kod Adı \\
\hline \multirow{3}{*}{ Sosyal } & Bilgi-Fikir Alışverişi \\
& Dayanışma-İşirliği \\
& Paylaşma \\
& Saygı Duyma \\
& Deneme-Yanılma \\
& Tartışma \\
Yöntem & Yeni Denemelerde Israrcı Olma \\
& Uzman Yardımı \\
& Fikirlerini Özgürce Belirtme \\
Bireysel Özellikler & Karar Verme \\
& Sabırlı olma \\
& Ciddiyet \\
& Sorumluluk \\
& Başarılı Olma Duygusu \\
& Fikir Geliştirme \\
& Çok Yönlü Düşünme \\
& Motivasyon \\
Duygu-Düşünce & Muhakeme ve Eleştirel Açıllık \\
& Uygulama \\
Sonuçlandırma & Alternatif Çözüm \\
& Bilgi Birikimi-Deneyim \\
& Bilgi Yetersizliği \\
Bireysel Yeterlilik & Alan Yeterliliği \\
& Mesleğe Sadakat \\
\hline
\end{tabular}

Öğretmen adaylarının vermiş oldukları cevaplardan örnekler;

"İlk de üzüldüm tabi ama üstüne gitmeye çalıştım sonuçta yapmak zorundayım, birşeyleri elde etmek zorundayım. O yüzden ilk başlarda üzüldüm tabi ki. Denedim tabi ki de ....bir şeyler koymaya çalıştım, yapamıyorsam başka insanlardan insanlardan kastım arkadaşlarım olur, hocalarım olur yardımlar almaya çalıştım......"

“.....ben genelde bir şey yapamadığım zaman sinirleniyorum o yüzden modum düşüyor ... sonra arkadaşlarıma sorduğumda düzeltiyoruz..."

"Bulmaya çalıştım.....STEM uygulamalarının kodlamalarda yaptığım çalışmalarda..sorun yaşadım..........deneyerek yaşayarak çözüm üretti....."

"Kötü hissediyoruz...alan eksikliğimizi aklımıza getiriyoruz..." 
"Sonuca ulaşamadığımda öğrenciye karşı kendimi yetersiz hissettim. Öğrenciden daha farklı bir mertebedeyiz ve kendimi duygusal olarak kötü hissettim...."

"ulaşamayınca bir yerden bir hata yaptığımızı fark ettik, bütün çeşitli yolları denedik, yeniden baştan kurduk olmadı ....olmadıysa alternatif bir şekilde gidermeye çalıştık..."

Öğretmen adaylarının vermiş oldukları cevaplar incelendiğinde bir önceki soruya vermiş oldukları cevaplara paralel cevap verdikleri tespit edilmiştir. Bununla birlikte çoğunlukla problemlerle karşılaştıklarında morallerinin bozulduğunu fakat problemleri çözmek için gerekli gayret ve çabayı gösterdiklerini, farklı çözüm yolları üretmeye çalıştıklarını belirtmişlerdir. Bunun için farklı bilgi kaynaklarına başvurarak hem farklı bilgi kaynaklarına ulaşmayı hemde bu kaynaklardan nasıl yararlanacaklarını öğrenmiş olduklarını vurgulamışlardır. Problemi çözme basamaklarını öğrendikleri yani tanıma, probleme etki eden kaynakları tespit etme, analiz etme, yorumlama ve çözüm yolu üretme becerisini kazandıklarını düşündükleri tespit edilmiştir.

"Karşılaştı̆̆ını bir problemle sonuca ulaşamayacă̆ınızı bilseniz bile yine de yeniden yeni yollar aramaya, bulmaya çalışır misınız? " sorusuna göre öğretmen adaylarının verdikleri cevaplardan 5 kategori ve 14 kod oluşturulmuştur.

Tablo 4: Katılımcıların sonuca ulaşamayacaklarını bilseler bile göstermiş davranışlar

\begin{tabular}{ll}
\hline Kategori & Kod Adı \\
\hline Yöntem & Yeni Denemelerde Israrcı Olma \\
& Araştırmaya Güvenme \\
& Özgüven \\
Bireysel Özellikler & Yeniliğe Açık Olma \\
& İstekli Olma \\
& Kararlı olma \\
& Sabırlı olma \\
& Başarılı Olma Duygusu \\
& Fikir Geliştirme \\
Duygu-Düşünce & Umut \\
& Eğlence \\
& Uygulama \\
Sonuçlandırma & Alternatif Çözüm \\
Bireysel Yeterlilik & Alan Yeterliliği \\
\hline
\end{tabular}

Öğretmen adaylarının vermiş oldukları cevaplardan örnekler;

"Evet çalışırım..."

"Ben herhalde çalışmam....."

"Ben hislerimle hareket ettiğim için eğer onun kötü olacağını düşünüyorsam devam ettirmem....."

"Kötü olursa orada birakırım, yeni yollar ararım....."

Öğretmen adaylarının vermiş oldukları cevaplar incelendiğinde; bir kısmının denemek istemediği tespit edilmişken genelinin denemek istediği ve bunun için gereken gayreti ve çabayı yapacaklarını düşündükleri tespit edilmiştir. Bazıları bu gayreti; sonuca ulaşmayı umut ettikleri ve sonuca ulaşmak istedikleri, bazıları kararlı bir yapıya sahip oldukları, bazıları başarma duygusunu tatmak istedikleri, bazıları ısrarcı bir yapıya sahip oldukları düşüncesiyle gösterdikleri tespit edilmiştir. Bunu yaparken kullanmış oldukları yöntem, amaç ve kazanımları açısından diğer sorulara vermiş olduklara cevaplara paralel cevaplar vermişlerdir. Örneğin bu çabaları etkinlikleri yapmaya karşı istekli 
olma ve eğlenceli bulma, yeni denemelerde ısrarlı olma, özgüvenli olma, yeniliğe açık olma gibi kişisel özelliklerin, alan yeterliliği gibi mesleki yeterliliklerin vealternatif çözüm yolları ve yeni fikir üretme, uygulamaya eğilimli olma gibi zihinsel eğilimlerin önemine vurgu yapmışlardır

Öğretmen adaylarının "Yapmış olduğunuz STEM etkinliklerinden sonra karşınızaçıkan bir probleme yönelik tutumunuzda ve düşüncelerinizde ne gibi değişiklikler oldu?" sorusuna göre öğretmen adaylarının verdikleri cevaplardan 6 kategori ve 20 kod oluşturulmuştur.

Tablo 5: STEM Eğitiminin katılımcıların problem çözme becerilerine etkisi düşünceleri

\begin{tabular}{ll}
\hline Kategori & Kod Adı \\
\hline \multirow{3}{*}{ Sosyal } & Dayanışma-İşbirliği \\
& Paylaşma \\
& Saygı Duyma \\
& Deneme-Yanılma \\
& Tartışma \\
Yöntem & Yeni Denemelerde Israrcı Olma \\
& Günlük Yaşamla İlişsilendirme \\
& Zit Düşünme Çürütme \\
& İstekli Olma \\
Bireysel Özellikler & Karar Verme \\
& Sorumluluk \\
& Kendini İfade Etme Başarısı \\
& Başarılı Olma Duygusu \\
& Çok Yönlü Düşünme \\
Duygu-Düşünce & Motivasyon \\
& Uygulama \\
Sonuçlandırma & Alternatif Çözüm \\
& Bilgi Birikimi-Deneyim \\
Bireysel Yeterlilik & El Becerisi \\
& Alan Yeterliliği \\
\hline
\end{tabular}

Öğretmen adaylarının vermiş oldukları cevaplardan örnekler;

"Biz STEM'de pratik zekâyı daha çok önplana çıkarttık. Bundan dolayı önüme çıkan problemlerde pratik zeka ....daha kolay yöntemlere başvurdum. O yüzden etkiliydi.."

"Olumlu bir etkisi oldu........"

“....tartışmaya girdik ne olabilir diye.....herkes başkasına ...sordu .......yeni yöntemler aramayı ögrendik, farkl yöntemler.....teknikler geliştirdik...”

"bir şeyi yapamayıp denemeden bırakmak var sürekli deneyip doğruya ulaşmak var bu yönde biraz ilerleme oldu...günlük hayatta karşılaştığımız şeylerin aslında STEM olduğunu görmüş olduk, bunu ögrencilere gösterdik ve günlük hayattan örnekler vererek anlattık... etkin bir öğrenim sağlayarak hem biz kendimize hem de öğrencilere fayda să̆ladık"

“önceden daha doğrusal bakıyordum şimdi daha geniş açıyla problemi nasıl çözebileceğimi ögrenmiş oldum..."

“......̈̈̆grendiğimiz, yaptı̆̆ımız materyaller değil de bunun gibi birçok şeyi de kendimiz ..yapabileceğimizi düşünüyorum...”

Öğretmen adaylarının STEM Eğitimi sırasında karşılaşmış oldukları problemlerin onların üzerinde pekçok etkisinin olduğunu düşündükleri saptanmıştır. $\mathrm{Bu}$ etkiler sosyal bakımdan 
incelendiğinde; karşısındaki bireyi güzel bir biçimde dinleyebilme yani iyi bir dinleyici olma, insanlar arası ilişkilerde daha pozitif bir tutum sergileme, insanlara güvenme, saygı duyma, uzlaşmacı olma, paylaşma, bilgi ve fikir alış verişinde bulunma ve dayanışma, işbirliğgi içinde olma tutumlarının geliştiğini düşündüklerini belirtmişlerdir. STEM etkinlikleri yalnızca bu becerileri kazandırmak için etkili bir yol olmadığını ve gerçek yaşamda karşılaşılan problemleri çözmeye yönelik becerilerini geliştirmede etkili bir yol olduğunu düşündükleri tespit edilmiştir. Öğretmen adaylarının STEM Eğitiminin problem çözmek için kullanmış oldukları yöntemlere de etkisinin olduğunu düşündükleri tespit edilmiştir. Araştırma yapmaya karşı pozitif tutum sergileme, araştırma yöntemlerini kullanma ve araştırdığında bilgiye ulaşabileceğine inanma, zıt düşünceleri mantık çerçevesinde çürütebilme, deneme yanılma yöntemini kullanma sıklıklarının artması ve bunu nasıl yapacaklarını daha iyi bilme, akranlar ile tartışarakbilgiyi analiz etme ve doğru bilgiye karar verme, yeni denemelere açık olma ve başka yöntemler deneme konusunda istekli ve ısrarcı olma, olay ve olguları günlük yaşamla ilişkilendirme ve böylece günlük yaşamda karşılaşılan durumlara daha rahat çözüm yolu bulma becerilerinin geliştiğini düşündükleri tespit edilmiştir.STEM Eğitiminin problem çözme becerilerinin temelini oluşturan bazı bireysel özelliklerinede etkisinin olduğunu düşündükleri saptanmıştır. Bunlar; problem çözmeye karşı istekli, sabırlı ve cesaretli olma, sorumluluk alma, karar verme, fikirlerini zıt düşüncede olan kişilere bile özgürce ifade etme ve gerektiğinde savunma olarak belirtmişlerdir. Ayrıca yeni fikirler geliştirme, alternatif çözüm üretme, çok yönlü düşünme becerisi kazanma, muhakame yapma ve fikirlerine karş1 eleştireye açı olma ve eleştirel düşünme becerisi kazanma, farklı fikirleri değerlendirerek ortak çözüm üretme gibi becerilerinin geliştiğini düşündükleri belirlemiştir. Problemleri çözmek için var olan bilgileri kullanma ve yeni bilgiler elde etme, el becerisi geliştirme, uygulama yapma, böylece hem alan yeterliliği kazanma hemde günlük yaşama hazırlanma olarak gördükleri saptanmıştır. Bu ifadeye ek olarak öğretmen adayları hem kendi gelişimlerine hem öğrencilerinin gelişimlerine katkı sağladıklarını belirtmektedirler. Bu noktadan sonra yapmakta oldukları etkinlik ya da materyaller değil de daha gerçekçi eleştirel düşünmeler yaparak gerçek yaşamda artık her şeyin üstesinden gelebileceklerini ifade etmektedirler. Bireyler STEM etkinlikleri sayesinde neleri yapıp yapamayacaklarına yönelik öz eleştiriler geliştirmişlerdir. En önemlisi yapabilecekleri yönünde kendilerine olan özgüvenleri arttı̆̆ını belirtmektedirler.

\section{Tartışma, Sonuç ve Öneriler}

Çalışmanın sonucunda STEM eğitiminin fen bilgisi öğretmen adaylarının problem çözme becerisine yönelik anlamlı ve olumlu etkisinin olduğu saptanmıştır. Öğretmen adaylarının yapmış oldukları odak gurup görüşmesinden elde edilen sonuçlar ilenicel veriler birbirini destekler durumdadır. $\mathrm{Bu}$ durum STEM Eğitimi boyunca uygulanan etkinliklerin öğretmen adaylarının sürekli olarak problemlerle karşılaşarak ve bu problemleri çözmek için farklı disiplinlerdeki bilgileri de kullanacak şekilde düzenlenmesinden kaynaklandığı söylenebilir. Çünkü böylece öğretmen adayları sürekli yeni problemlerle karşılaşmış ve yeni bilgiye ve yeni çözüm yollarına ihtiyaç duymuşlardır. Literatürde STEM tanımlamaları ve STEM'in problem çözme becerisiyle ilintisine dikkat edildiğinde ayrılmaz bir bütün olduğu görülmektedir. STEM bireylerin problem çözmelerinde çeşitli alanlarda bulunan bilgi, beceri, kavram ve olgulardan faydalanmalarını sağlayan eğitim yaklaşımıdır (Vasquez, 2014). STEM bireylerin karşılaşmış oldukları problemi analiz ederek yaratıcı çözümler üretme ve bu çözümler arasından uygun olanı seçerek çözüme ulaşma süreçleri öğrencilerin problem çözme becerilerini geliştirmelerine etki etmektedir (Acar, 2020: 85). STEM Eğitimi bireylere, sorunlara disiplinlerarası perspektifle yaklaşarak 21. yy beceri ve bilgilerini kazandırmaya çalışmakta, alansal uzmanlaşmaya odaklanmaktadır (Tezel \& Yaman, 2017: 140). Alanlar arası çalışma avantajı oluşturmasıyla bireylerin esas becerilerine (eleştirel düşünme ve problem çözme gibi) olumlu yönde katkıları içermektedir (Australian Educ. Councill, 2015).

Ayrıca çalışmanın sonucunda öğretmen adaylarının araştırma yapmaya karşı pozitif tutum sergileme, araştırma yöntemlerini kullanma ve araştırdığında bilgiye ulaşabileceğine inanma, zit düşünceleri mantık çerçevesinde çürütebilme, deneme yanılma yöntemini kullanma sıklıklarının artması 
ve bunu nasıl yapacaklarını daha iyi bilme, akranlar ile tartışarak bilgiyi analiz etme ve doğru bilgiye karar verme, yeni denemelere açık olma ve başka yöntemler deneme konusunda istekli ve israrcı olma, olay ve olguları günlük yaşamla ilişkilendirme ve böylece günlük yaşamda karşılaşılan durumlara daha rahat çözüm yolu bulma becerilerinin geliştiğini düşündükleri tespit edilmiştir. Bununla birlikte çoğunlukla problemlerle karşılaştıklarında morallerinin bozulduğunu fakat problemleri çözmek için gerekli gayret ve çabayı gösterdiklerini, farklı çözüm yolları üretmeye çalıştıklarını belirtmişlerdir. Bunun için farklı bilgi kaynaklarına başvurarak hem farklı bilgi kaynaklarına ulaşmayı hemde bu kaynaklardan nasıl yararlanacaklarını öğrenmiş olduklarını vurgulamışlardır. Problemi çözme basamaklarını öğrendikleri yani tanıma, probleme etki eden kaynakları tespit etme, analiz etme, yorumlama ve çözüm yolu üretme becerisini kazandıklarını düşündükleri tespit edilmiştir. STEM, problem çözme konularında öğrenci merkezli olup araştırmaya dayalı bir eğitim öğretim yöntemidir (Kara, 2018). STEM eğitim modeliyle günümüz becerilerinin gelişimleri desteklenmektedir (Bybee, 2010; Australian Educ. Councill, 2015; Toulmin \& Groome, 2007: 16). Stohlmann, Moore ve Roehrig (2012: 29) STEM Eğitimi yoluyla bireylerin problem çözme becerilerini geliştirmelerine, yenilikçi düşünmelerine, özgüvenlerini artırmalarına ve analitik düşünme basamaklarına katkı sağlayacaklarını vurgulamaktadır. $\mathrm{Bu}$ tanımlamalarla olumlu ve anlamlı farkın ortaya çıkmasında STEM'in pratiğe olanak vermesi sebebiyle uygulayanların düşünmelerinde eleştirelliği ilerleterek rastlanılan sorunlara çözüm üretmelerini destekleyen yapısı ve fenin doğasında bulunan bilimsel süreç becerileri ile günlük yaşamdan ayrılmaz yapısı düşünüldüğünde elde edilen sonucun doğal olduğu düşünülmektedir. STEM bireylerin problem çözme becerilerini geliştirmekte ve gündelik yaşamlarındaki sorunlarına yanıt bulmalarını sağlamaktadır (Ceylan, 2014; Morrison, 2006; Niess, 2005; Wang, 2012; Y1ldırım, 2016). Eğitim modeli STEM odaklı çerçevede kurgulanan derslere fen'in dâhil edilmesi; bu alanlara ilişkin bilgi ve beceri gerektiren sorunların çözüm sürecinde araştırma ve sorgulama süreçlerinden faydalanılmasını öngörür (Bozkurt - Altan, vd. 2016: 228). Bu bakımdan bireylerin akademik başarılarından çok ana temelde gerçek yaşamda karşılaştıkları gündelik yaşam problemlerine katkı sağlayarak bakış açılarına farklılık getirdiği, bireyler arası etkileşimlere atmosfer oluşturduğu önemli bulunmaktadır. STEM uygulamaları bireylerin rutin hayatlarında problem çözme becerisini ilerleterek öğrendiklerini farklı problemlerin çözümünde deneyimlemelerine katkıda bulunmaktadır (Flanders State of Art, 2018; Pekbay, 2017).

Çalışmanın nitel verilerinin sonucunda; STEM Eğitiminin problem çözme becerilerinin temelini oluşturan bazı bireysel özelliklerine de etkisinin olduğunu düşündükleri saptanmıştır. Bunlar; problem çözmeye karşı istekli, sabırlı ve cesaretli olma, sorumluluk alma, karar verme, fikirlerini zıt düşüncede olan kişilere bile özgürce ifade etme ve gerektiğginde savunma olarak belirtmişlerdir. Ayrıca yeni fikirler geliştirme, alternatif çözüm üretme, çok yönlü düşünme becerisi kazanma, muhakame yapma ve fikirlerine karşı eleştireye açık olma ve eleştirel düşünme becerisi kazanma, farklı fikirleri değerlendirerek ortak çözüm üretme gibi becerilerinin geliştiğini düşündükleri belirlemiştir. Problemleri çözmek için var olan bilgileri kullanma ve yeni bilgiler elde etme, el becerisi geliştirme, uygulama yapma, böylece hem alan yeterliliği kazanma hemde günlük yaşama hazırlanma olarak gördükleri saptanmıştır. Wang vd., (2011) STEM eğitimi alan öğretmenlerin STEM eğitiminde problem çözme sürecinin etkili olduğunu fark ettiklerini belirtmişlerdir. Bu durum yeni bilgi ve deneyimler elde etme ve bilgi elde etme basamak ve becerilerini geliştirme, farklı çözüm yolları üretme ve bunları deneyimleme hatta problem çözme basamaklarını öğrenmelerine olanak sağlamaktadır (Kelley \& Knowles, 2016). Öğrencilerin öğrendikleri bilgileri günlük hayattan uzak bir şekilde öğrenmeleri ve bilgileri birbirleriyle ilişkilendirilmediğinde disiplinler arası bağlantı olmadığında matematik ve fen derslerine ilgilerinin azalacağı sonucuna ulaşılmıştır. Tarkın Çelikkıran \& Aydın Günbatar (2017: 1652) tarafından yapılan çalışma da STEM Eğitimi alan kimya öğretmen adaylarının konuları günlük hayatla ilişkilendirebildikleri ve problemleri daha eleştirel bir bakış açısı ile ele aldıkları belirlenmiştir. STEM Eğitimi; bireylerin farklı bakış açısı kazanma, yaratıcılığı ortaya koyma, iletişim gücünü artırma, kişilerarası doğru ve etkili iletişimde bulunma, fikir üretme ve fikrini başka bireylerle paylaşma ve gerktiğinde savunmaaçısından öenmli bir etkiye sahiptir (Kara, 2018). 
Çalışmanın sonucunda öğretmen adaylarının karşısındaki bireyi güzel bir biçimde dinleyebilme yani iyi bir dinleyici olma, insanlar arası ilişkilerde daha pozitif bir tutum sergileme, insanlara güvenme, saygı duyma, uzlaşmacı olma, paylaşma, bilgi ve fikir alış verişinde bulunma ve dayanışma, işbirliği içinde olma tutumlarının geliştiğini düşündükleri tespit edilmiştir. STEM; bireylere disiplinlerarası düşünme yetisi kazandırarak, işbirliği içinde çalışmada deneyimler sunarken, temelde yaşama dair problemlere çözüm bulmalarına temel oluşturmaktadır (Dugger, 2010; Akdağ \& Güneş, 2015: 1653). STEM temelini oluşturan disiplinlerin birbirleriyle nasıl etkileşim içinde olduğunu görerek problemi bütüncül olarak ele alma ve çözüm üretmenin bir yoludur. Problem temellidir ve çözüm odakl1 yaklaşmayı yani bakış açısı kazanmayı esas almaktadır (Brown vd., 2012: 3). Tüm bu çalışmalara ek olarak öğretmen adaylarının STEM eğitiminin bireylerin özgüvenlerini geliştirdiği çalışmalar da bulunmaktadır. STEM eğitiminin problem çözme becerileri ve bilgi-becerilerin kullanılarak yaratıcılıkların, özgüvenin geliştirilmesinde, mantıksal düşünmelere katkı sağlamada, teknolojiyi kullanmada, doğayı anlama ve açıklamada faydaları bulunmaktadır (Yıldırım ve Altun, 2015: 36). Bununla birlikte öğretmen adaylarının ifadelerine bakıldığında hem kişisel gelişimlerine hem öğrencilerinin kişisel gelişmelerine fayda sağladıklarını belirtmektedirler. Ek olarak sorunlarına doğrusal nitelikte baktıklarını, yanıtının yek olabileceğini düşünürken STEM'e yönelik faaliyetler sayesinde çok taraflı bakış açıları ile çözüme yönelik çeşitli alternatif yollar geliştirdiklerini ifade etmektedirler. Bunun yanı sıra yapmakta oldukları faaliyet ya da materyaller yerine daha realist eleştirel düşünmeler yaparak hayatlarında her şeyin üstesinden gelebileceklerini belirtmektedirler. Bireyler STEM faaliyetleriyle neleri yapıp yapmayacaklarına ilişkin öz eleştiriler geliştirmiş olduklarını, bundan daha önemlisi öz benliklerine olan güvenlerinin arttığını ve yine öğretmen adayları tarafindan STEM' in bilgi, yetenek, davranış ve artıları olanaklı kıldığını açıklamışlardır (Wendell vd., 2010). Şahin vd. (2014: 318) çalışmalarında, STEM eğitimitemele alınarak gerçekleştirilen etkinliklerinin bireylerin işbirliği yapma becerilerinin geliştiği ve işbirliğine karşı olumlu tutum sergiledikleri tespit edilmiştir.

$\mathrm{Bu}$ bağlamda üst seviye yetenekleri karş1layan yöntemlerden biri olmasıyla STEM; fertleri, kuşakları yetiştirecek öğretmenlerimizin donanımlarını arttıracak durumda bulunmasını sağlamaktadır (Crawford vd., 2011; Robinson vd., 2007: 22; Stauffer \& McMullin, 2009: 66). Ancak öğrenim durumundaki her bireyin kabiliyetinin gelişimi geç bulunmakla beraber öğretenlerin de aynı sistemde yetiştiğinin düşünülmesiyle çıkmaz durum onaylanmaktadır. Buradaki düşünceyle aileden başlayarak öğretmenlerle gelişim sürdüren bireylerin STEM' e teşviki doğru bulunmaktadır. O yüzden öğrenciyken her birey gibi iyi bir eğitim süreci geçirdiği varsayılan öğretmen adaylarının fakültelerde de muntazam eğitimler tatmış olmalıdır. Her insan bahsedilen sebeplerden dolayı sonuçsuz döngüde kalmaktadır. Uygulamalardan biri olan STEM için, koşullanan eğitimi almaları gerekmektedir (Adıgüzel vd., 2012). MEB (2016)'in STEM 'e yönelik fiili düşüncesi bulunmaktadır. Adayların gelişimi ve STEM'in yayılması, pratikleştirilmesi ve sürdürülebilmesi, MEB' le beraber YÖK için de gerekmektedir. Literatürde öğretmen olanlar ve olacaklar ile yapılan çalışmalarda STEM öğrenimine ve mesleklerine olan ilginin ülke rekabetlerine yönlendirilmesi bu eğitimlerin önemine dikkat çekmektedir. MEB'in STEM raporu "STEM faaliyetleriyle bütünleşik dersleri işleyecek öğretmenler için eğitim fakültelerinde yetiştirme programlarına başlanmalı mıdır?" sorusu öğretmenlerce \%91.08 olarak yanıtlanmıştır (MEB, 2016). Günümüzde müfredata girdiği bilinmekte ancak yerini bulup bulmadığı düşünülmektedir. Kısaca araştırmanın sorgusu olan problem çözme sokratik kabiliyeti gerektirmektedir. Sokratik becerinin bireylere kazandırılması eğitim kademelerimizde geç gerçekleşmektedir. Öğretmenlerin fakültelerde STEM yoluyla gelişmesi, STEM mesleklerine yönelen öğrencilerin yetişmesi bakımından önem arz etmektedir. Bu öğrencilerin gerçek yaşamlarındaki sorunlara çare bulabilmeleriyle ülke kalkınması için güce ulaşması gerekmektedir. Bütün öğrenme süreçlerinde farklı yöntem ve tekniklerin devamı doğal olarak söz konusudur. Çözüm odaklı öğrenmeler yoluyla fertleri, içinde bulunduğumuz zaman ekonomisinin siluetindeki geleceğe hazırlayabileceğimiz gerçektir (Aydeniz, 2017).

Özellikli kuşakların yetişmesi ertelenemez durumdadır. Mesleki kimlikler olmaksızın öğretmenin de toplumun bir parçası olduğu düşünüldüğünde tüm bireyleri kapsayan ve yetiştiricilik 
sorumluluğunu üstlenen öğretmenlerin bilimsel verilere dayanarak istendik davranışlarının geliştirilmesi temel alınarak araştırmamız önemini ortaya koymaktadır. Ayrıca hâlihazırdaki öğretmenlerimize düssen sorumluluklar da araştırmamızın önemine vurgu yapmaktadır. Öğretmenler nasıl öğrenirse o şekilde öğreteceğinden, öğretenlerin özgün etkileşimlerin farkında olarak eğitimin niteliği gereği problem çözme, Bilim süreç becerileri, çok yönlü öğrenme-öğretme stilleriyle bireysel farklılıkları dikkate alan bilgide ve beceri de olmalıdır. Her eğitim kademesinde öğretmenler kişisel durumlarını geri planda bırakmalı ve objektif tutum ve davranışta bulunmalıdırlar. Bu araştırma başka araştırmalarla uyumlu görünse de ülkemiz gerçeklerini açık ve net belirtebilmesi için farklı üniversitelerin eğitim fakülteleri hatta farklı fakülteleriyle benzer nitelikte yeni çalışmaların yapılması yarar sağlayacaktır. STEM'in fen bilgisi öğretmen adaylarının problem çözme becerilerine etkisinin irdelenmesi bilimin, fen eğitiminin niteliğine, farklı görüş ve yaklaşımların geliştirilmesine katkı sağlayacaktır. Öğretmen adaylarının fikirleri, STEM' in standardına uygun yapılması; fen eğitimine katkıda bulunması, nitelikli bireylerin yetişmesi, bilgi-becerilerin geliştirilmesi adına ülkemiz için harikulade bir duruş olacaktır.

\section{Kaynakça}

Acar, D. (2020). Öğretmenlerin problem çözme becerilerinin ve davranışlarının yaratıcı düşünmenin gelişimine katkısının yordanmasında STEM farkındalıklarının rolü. Academia Eğitim Araştırmaları Dergisi, 5(1), 77-89.

Adigüzel, T., Ayar, M. C., Corlu, M. S. \& Özel, S. (2012, Haziran). Fen, teknoloji, mühendislik ve matematik (FeTeMM) eğitimi: Disiplinlerarası çalışmalar ve etkilişimler [Kongrede sunulmuştur]. 10. Ulusal Fen Bilimleri ve Matematik Eğitimi Kongresi

Akdağ, F. T. \& Güneş, T. (2015). Enerji konusunda yapılan STEM uygulamaları ile ilgili Fen Lisesi öğrenci ve öğretmen görüşleri. International Journal of Social Sciences and Education Research, 3(5), 1643-1656.

Akins, L. \& Burghardt, D. (2006, October). Work in progress: Improving $K-12$ mathematicsunderstanding with engineering design projects [Conference Presentation]. In Proceedings from the 36thASEE/IEEE Frontiers in Education Conference. New York, US.

Aslan Yolcu, F. (2014, Nisan 24-26). Ortaokul düzeyinde performans görevi uygulamaları sürecinde disiplinler arası yaklaşımın öğrencilerin problem çözme becerileri üzerindeki etkisi [Konferansta sunulmuşstur]. EJER Congress, İstanbul, Türkiye.

Australian Education Council. (2015). National STEM School Education Strategy 2016- 2026. http://www.educationcouncil.edu.au/site/DefaultSite/filesystem/documents/National\%20STE M\%20School\%20Education\%20Strategy. Pdf

Aydeniz, M. (2017). Eğitim sistemimiz ve 21. Yüzyıl hayalimiz: 2045 Hedeflerine ilerlerken, Türkiye için STEM odaklı ekonomik bir yol haritası. University of Tennessee, Knoxville. https://trace.tennessee.edu/utk_theopubs/17/

Bilekyiğit, Y. (2018). Biyoloji dersinde gerçekleştirilen STEM etkinliğinin meslekî veteknik anadolu lisesi ögrencilerinin akademik başarılarına ve kariyer ilgilerine etkisinin incelenmesi [Yüksek lisans tezi]. Karamanoğlu Mehmetbey Üniversitesi Fen Bilimleri Enstitüsü.

Bingham, A.(2004). Çocuklarda problem çözme yeteneklerinin geliştirilmesi. (F. Oğuzkan, Çev.). Milli Ĕ̈itim Basımevi.

Bingolbali, E., Monaghan, J. \& Roper, T. (2007). Engineering students' conceptions ofthe derivative and some implications for their mathematical education. International Journal of mathematical 


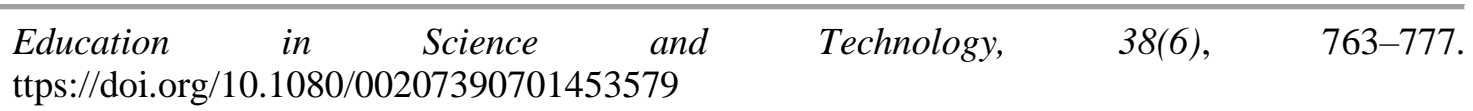

Büyüköztürk, Ş., Kılıç- Çakmak, E., Akgün, Ö. E., Karadeniz, Ş. \& Demirel, F. (2016). Bilimsel araştırma yöntemleri. Pegem Yayınc1lık.

Bozkurt, E. (2014). Mühendislik tasarım temelli fen eğitiminin fen bilgisi öğretmen adaylarının karar verme becerisi, bilimsel süreç becerileri ve sürece yönelik algılarına etkisi [Yayımlanmamış doktora tezi]. Gazi Üniversitesi Eğitim Bilimleri Enstitüsü.

Bozkurt- Altan, E., Yamak, H. \& Buluş- Kırıkkaya, E. (2016). FeTeMM eğitim yaklaşımının öğretmen eğitiminde uygulanmasına yönelik bir öneri: Tasarım temelli fen eğitimi. Trakya Üniversitesi Eğitim Fakültesi Dergisi, 6(2), 212-232.

Boyle, J. (2019). Teaching gravitational waves in the lower secondary school. Part III. Monitoring the effect of a STEM intervention on studentse attitude, self-efficacy and achievement. Physics Education, 54(2), 025007. https://doi.org/10.1088/1361-6552/aaf771

Brown, H.B., Martinez, D. \& Times, C. (2012). Engaging Diverse Learners through the Provision of STEM Education Opportunities. Briefing Paper. Southeast Comprehensive Center. https://files.eric.ed.gov/fulltext/ED573497.pdf

Bybee, R. W. (2010). Advancing STEM education: A 2020 Vision. Technology and Engineering Teacher, 70(1), 30-35.

Can, G. (1987). Öğretmenlik meslek anlayışı üzerine bir araştırma. Anadolu Üniversitesi Eğitim Fakültesi Dergisi, 1(2), 159-170.

Capobianco, B. M. (2011). Exploring a science teacher's uncertainty with integrating engineering design: An action research study. Journal of Science Teacher Education, 22, 645-660. https://doi.org/10.1007/s10972-010-9203-2

Capobianco, B. M. (2013). Learning and teaching science through engineering design: insights and implications for professional development. Charleston, SC: Association for Science Teacher Education.

Carr, K. S. (1990). How can we teach critical thinking. ERIC Clearinghouse on Elementary and Early Childhood Education Urbana IL, 1-5.

Cho, B. \& Lee, J. (2013). The effects of creativity and flow on learning through thesteam education on elementary school contexts [Conference presentation]. International Conference of Educational Technology.

Ceylan, S. (2014). A study for preparing an instructional design based on science, technology, engineering and math (stem) approach on the topic of acids and bases at secondary school science course [Unpublished master dissertation]. Uludag University Institute of Education Sciences

Clarke, K. C. (2010). A science, engineering and technology (SET) approach improves science process skills in 4-h animal science participants. Journal of ExtensionSharing Knowledge, Enriching Extension, 48(1), article 1IAW3. http://www.joe.org/joe/2010february/iw3.php.

Cotabish, A., Dailey, D. Robinson, A. \& Hunghes, G. (2013). The Effects of a STEM intervention on elementary students' science knowledge and skills. School Science and Mathematics, 113(5), 215-226.

Crawford, P., Lang, S., Fink, W., Dalton, R. \& Fielitz, L. (2011). Comparative analysis of soft skills: What is important for new graduates?. Washington, DC: Association of Public and Land-grant Universities. 
Creswell, J. W. (2002). Educational research: Planning, conducting, and evaluating quantitative and qualitative research. Upper Saddle River.

Creswell, J W. (2012). Educational research: Planning, conducting, and evaluating quantitative and qualitative research. Boston: Pearson.

Cresswell, J. W. \& Plano Clark, V. L. (2007). Desiging and conducting mixed method research. Sage Publications.

Cüceloğlu, D. (2003). İnsan ve davranışı: Psikolojinin temel kavramları. İstanbul: Remzi Kitabevi

Çalışkan, M., Işık, A. N. \& Saygın, Y. (2013). Öğretmen adaylarının ideal öğretmen algıları. lköğretim Online, 12(2), 575-584.

Çepni, S. (2005). Araştırma ve proje çalışmalarına giriş. Üçyol Kültür Merkezi.

Çınar, S. Pirasa, N., Uzun, N. \& Erenler, S. (2016). The Effect of STEM Education on Pre-service Science Teachers' perception of interdisciplinary education. Journal of Turkish Science Education, 13(special issue), 118- 142.

Çokluk, Ö. Yılmaz, K. \& Oğuz, E. (2011). Nitel Bir Görüşme Yöntemi: Odak Grup Görüşmesi. Kuramsal Eğitim Bilim, 4 (1), 95-107.

Denson, C. D. (2011). Building a framework for engineering design experiences in STEM: A synthesis. http://ncete.org/flash/pdfs/Denson\%20Synthesis.pdf

Dewaters, J. \& Powers, S. E. (2006, June 1-11). Improving science and energy literacy throughprojectbased K-12 outreach efforts that use energy and environmental themes [Conference Presentation]. Proceedings of the 113th Annual ASEE Conference and Exposition

Dinçer, Ç. (1995). Anaokuluna devam eden 5 yaş grubu çocuklarına kişilerarası problem çözme becerilerinin kazandırılmasında eğitimin etkisinin incelenmesi [Yayınlanmamış doktora tezi]. Hacettepe Üniversitesi Sağl1k Bilimleri Enstitüsü.

Dugger, W. E. (2010, December 8-11). Evolution of STEM in the United State [Conference presentation]. At the 6th Biennial International Conference on Technology Education Research

Dym, C.L., Wood, W.H. \& Scott, M.J. (2002). Rank ordering engineering designs: Pairwise comparison charts and borda counts. Research in Engineering Design, 13, 236-242. https://doi.org/10.1007/s00163-002-0019-8

Edmunds, H. (2000). The focus group research handbook. McGraw-Hill

Eroğlu, S. \& Bektaş, O. (2016). STEM eğitimi almış fen bilimleri öğretmenlerinin STEM temelli ders etkinlikleri hakkındaki görüşleri. Eğitimde Nitel Araştırmalar Dergisi, 4(3), 43-67. https://doi.org/10.14689/issn.2148-2624.1.4c3s3m

Figliano, F. (2007). Strategies for integrating STEM content: A pilot case study [Unpublished masters dissertation]. Virginia Polytechnic Institute and State University.

Flanders State of Art. (2018). STEM Framework for Flemish Schools Principles and Objectives. https://www.onderwijs.vlaanderen.be/sites/default/files/atoms/files/STEM-kader\%20\% 28Engels \%29.pdf.

Guzey, S. S., Moore, T. J., Harwell, M. \& Moreno, M. (2016). STEM integration in middle school life science: Student learning and attitudes. Journal of Science Education and Technology, 25(4), 550-560. https://doi.org/10.1007/s10956-016-9612-x

Gökbayrak, S. \& Karışan, D. (2017). STEM etkinliklerinin fen bilgisi öğretmen adaylarının bilimsel süreç becerilerine etkisi. Batı Anadolu Ĕgitim Bilimleri Dergisi, 8(2), 63-84. 
Heppner, P. P. \& Peterson, C. H. (1982). The development and implications of a personal problem solving inventory. Journal of Counseling Psychology, 29(1), 66-75. https://doi.org/10.1037/0022-0167.29.1.66

Johnson, R. B., Onwuegbuzie, A. J. \& Turner, L. A. (2007). Toward a Definition of Mixed Methods Research. Journal of Mixed Methods Research, 1(2), 112-133.

Jonassen, D. H. (2011). Design problems for secondary students. http://ncete.org/flash/pdfs/Design_

Problems_Jonassen.pdf

Kalayc1, N. (2001). Sosyal bilgilerde problem çözme ve uygulamalar. Gazi Kitabevi.

Kara, Y. (2018, October). Fen bilgisi öğretmeni adaylarının stem atölyesi üzerine görüşlerinin belirlenmesi [Conference Presentation]. International Conference on Education Research and Technologies.

Karc1, M. (2018). STEM etkinliklerine dayalı senaryo tabanlı öğrenme yaklaşımının (STÖY) öğrencilerin akademik başarıları, meslek seçimleri ve motivasyonlarıüzerine etkisinin incelenmesi [Yüksek lisans tezi]. Çukurova Üniversitesi Sosyal Bilimler Enstitüsü.

Kelley, T. R. \& Knowles, J. G. (2016). A conceptual framework for integrated STEM education. International Journal of STEM Education, 3(1), 11.https://doi.org/10.1186/s40594-016-0046-Z

Kim, G. S. \& Choi, S. Y. (2012). The effect of creative problem solving ability and scientific attitude through the science based STEAM program in the elementary gifted students. Elementary Science Education, 31(2), 216-226.

Kitzinger J. (1994). The methodology of focus groups: the importance of interaction between research participants. Sociology of Health 16 (1), 103-121. https://doi.org/10.1111/14679566.ep11347023

Kitzinger, J. (1995) “Qualitative research: introducing focus groups”, British Medical Journal, 311, 299 302. https://doi.org/10.1136/bmj.311.7000.299

Kırgız, H.,\& Koyuncu, A. (2016). Bilim merkezlerinin uluslararası sınavlardaki başarıya etkisi. Informal Ortamlarda Araştırmalar Dergisi, 1(1), 52-60.

Kwon, S. B., Nam, D. S. \& Lee, T. W. (2012). The Effects of STEAM-based integrated subject study on elementary school students' creative personality. The Korea Society of Computer and Information, 17(2), 79-86.

Langdon, D., Mckittrick, G., Beede, D., Khan, B. \& Doms, M. (2011). STEM: Good jobs now and for the future. U.S. Department of Commerce Economics and Statistics Administration, 3(11), 2. https://files.eric.ed.gov/fulltext/ED522129.pdf

Lie, R., Guzey, S. S. \& Moore, T. J. (2019). Implementing engineering in diverse upper elementary and middle school science classrooms: student learning and attitudes. Journal of Science Education and Technology, 28(2), 104-117. https://doi.org/10.1007/s10956-018-9751-3

Lou, S-J., Shih, R-C., Diez, C. R. \& Tseng, K. H. (2011). The impact of problem- based learningstrategies on STEM knowledge integration and attitudes: An exploratory study amongfemale Taiwanese senior high school students. International Journal of Technology and Design Education, 21(2), 195- 215.

Loughran, J.J. (2002). Effective reflective practice in search of meaning in learning about teaching. Journal of Teacher Education, 53(1), 33-43. 
Madden, L., Beyers, J. \& O'Brien, S. (2016). The importance of STEM education in the elementary grades: Learning from pre-service and novice teachers' perspectives. The Electronic Journal for Research in Science \& Mathematics Education, 20(5).

Martinello, M. L. (2000). Interdisciplinary inquiry in teaching and learning. Upper Saddle River: Gillian E. Cook.

MEB (2016). STEM Eğitimi Raporu. YEĞİTEK Milli Eğitim Bakanlı̆̆ı - Yenilik ve Eğitim Teknolojileri Genel Müdürlügü. http://yegitek.meb.gov.tr/STEM_Egitimi_Raporu.pdf

Merriam, S. B. (1998). Qualitative research and case study applications in education. San Francisco: Jossey-Bass.

Miller, M. \& Nunn, G. D. (2001). Using group discussion to 1mprove social problem solving and learning. Education, 121(3), 470-475.

Milli Ĕ̆itim Bakanlığı (2018a). Fen bilimleri dersi öğretim programı. Öğretim Programlarını İzleme ve Değerlendirme sistemi http://mufredat.meb.gov.tr/ProgramDetay.aspx?PID=325

Milli Eğitim Bakanlığı (2018b). Matematik dersi öğretim programı. Öğretim Programlarını İzleme ve Değerlendirme sistemi. http://mufredat.meb.gov.tr/Dosyalar/201813017165445MATEMAT\%C4\%B0K\%20\%C3\%96\%C4\%9ERET\%C4\%B0M\%20PROGRAMI\%202018v. pdf

Morrison, J. (2006). TIES STEM education monograph series, Attributes of STEM education. Baltimore, MD: TIES.

Niess, M. L. (2005). Preparing teachers to teach science and mathematics with technology: Developing a technology pedagogical content knowledge. Teaching and Teacher Education, 21, 509-523. https://doi.org/10.1016/j.tate.2005.03.006

Olkun, S. ve Toluk, Z. (2001). İlkögrretimde matematik ögrretimi: 1-5 sinıflar. Artım Yayınevi.

Öner, A. T. \& Capraro, R. M. (2016). Is STEM academy designation synonymous with higher student achievement? Education \& Science/Egitim ve Bilim, 41(185), 1-17. https://doi.org/10.15390/EB.2016.3397

Park, M., Nam, Y., Moore, T. J. \& Roehring, G. (2011). The impact of integrating engineering into science learning on student's conceptual understandings of the concept of heat transfer. Journal of the Korean Society of Earth Science Education, 4(2),89-101.

Pekbay, C. (2017). Fen teknoloji mühendislik ve matematik etkinliklerinin ortaokul ögrencileri üzerindeki etkileri [Yayımlanmış Yüksek Lisans Tezi]. Hacettepe Üniversitesi Eğitim Bilimleri Enstitüsü.

Perkins, D. N. (1994). The Intelligent eye. Santa Monica, CA: The Getty Center For Education In The Arts, 29(3), 117-119. https://doi.org/10.2307/3333548

Riskowski, J. L., Todd, C. D., Wee, B., Dark, M. \& Harbor, J. (2009). Exploring the effectiveness of an interdisciplinary water resources engineering module in an eighth grade science course. International Journal of Engineering Education, 25 (1), 181-195.

Robinson, J. S., Garton, B. L. \& Vaughn, P. R. (2007). Becoming employable: A look at graduates' and supervisor" perceptions of the skills needed for employability. NACTA Journal, 51(2), 19-26. https://doi.org/10.2307/43766145

Sarı, H. \& Bozgeyikli, H. (2003) Öğretmen adaylarının özel eğitime yönelik tutumlarının incelenmesi: karşılaştırmalı bir araştırma. Selçuk Üniversitesi Sosyal Bilimler Enstitüsü Dergisi, 9, 183-204. 
Sari, Y. S., Selisne, M. \& Ramli, R. (2019, April). Role of students worksheet in STEM approach to achieve competence of physics learning. In Journal of Physics: Conference Series, 1185(1).

Scott, C. (2012). An investigation of science, technology, engineering and mathematics (STEM) focused high schools in the US. Journal of STEM Education: Innovations \& Research, 13(5), 30-39.

Senemoğlu, N. (2001). Öğrenci görüşlerine göre öğretmen yeterlilikleri, eğitimde yansımalar. Öğretmen Hüseyin Hüsnü Tekışık Eğitim Araştırma Gelişstirme Vakfı Yayınları, 193-215.

Stauffer, D. F. \& McMullin, S. I. (2009). Desired competencies and perceived proficiencies of entrylevel fishers and wildlife professionals: A survey of employers and educators. Transactions of the North American Wildlife and Natural Resources Conference, 75, 62-68.

Stohlmann, M., Moore, T. \& Roehrig, G. (2012). Considerations for teaching integrated STEM education. Journal of Pre-College Engineering Education Research, 2(1), 28-34. https://doi.org/10.5703/1288284314653

Sullivan, F. V. (2008). Robotics and science literacy: Thinking skills, science process skills and systems understanding. Journal of Research in Science Teaching, 45(3), 373-394.

Şahin, A., Ayar, M.C. \& Adiguzel, T. (2014). STEM related after-school program activities and associated outcomes on student learning. Educational Sciences: Theory \& Practice, 14(1), 309322. https://doi.org/10.12738/estp.2014.1.18763

Şahin, N., Şahin, N. H. \& Heppner, P. P. (1993). Psychometric properties of the problem solving inventory in a group of Turkish university students. Cognitive Therapy and Research, 17(4), 379-396. https://doi.org/10.1007/BF01177661

Tarkın-Çelikkıran, A. \& Aydın-Günbatar, S. (2017). Investigation of pre-service chemistry teachers' opinions about activities based on stem approach. YYU Journal Of Education Faculty, 14(1), $1624-1656$

Tatar N. \& Kuru, M. (2006). Fen eğitiminde araştırmaya dayalı öğrenme yaklaşımının akademik başarıya etkisi. Hacettepe Üniversitesi Eğitim Fakültesi Dergisi, 31, 147-158.

Taylan, S. (1990). Heppner'in problem çözme envanterinin uyarlama, güvenirlik ve geçerlik çalışmaları [Yayınlanmamış Yüksek Lisans Tezi]. Ankara Üniversitesi.

Tezel, Ö., \& Yaman, H. (2017). A review of studies on STEM education in Turkey. Journal of Research in Education and Teaching, 6(1), 135-144

Tseng, K. H., Chang, C. C., Lou, S. J., \& Chen, W. P. (2013). Attitudes towards science, technology, engineering and mathematics (STEM) in a project-based learning (PjBL) environment. International Journal of Technology and Design Education, 23(1), 87-102.

Toulmin, C. N. \& Groome, M. (2007). Building a science, technology, engineering, and math agenda. National Governors Association, 1-24.

Varış, F. (1998). Temel kavramlar ve program geliştirmeye sistematik yaklaşım. Eğitim Bilimlerinde Yenilikler. Eskişehir Anadolu Üniversitesi Açıköğretim Yayınları.

Vasquez, J. (2014). STEM: beyond the acronym. Educational Leadership, 72(4), 10-15.

Wang, H. (2012). A New era of science education: science teachers " perceptions and classroom practices of science, technology, engineering, and mathematics (STEM) integration [Unpublished doctoral dissertation].

Wang, H. H., Moore, T. J., Roehrig, G. H. \& Park, M. S. (2011). STEM integration: Teacher perceptions and practice. Journal of Pre-College Engineering Education Research (J-PEER), 1(2), 1-13. https://doi.org/10.5703/1288284314636 
Varış, F. (1998). Temel kavramlar ve program geliştirmeye sistematik yaklaşım. Eskişehir Anadolu Üniversitesi Açıköğretim Yayınları.

Wells, R. (2008). The Global and the Multicultural: Opportunities, Challenges, and Suggestions for Teacher Education. National Association for Multicultural Education, 10(3), 142-149. https://doi.org/10.1080/15210960802197656.

Wendell, K., Connolly, K., Wright, C., Jarvin, L., Rogers, C., Barnett, M., \& Marulcu, I. (2010, October). Incorporating engineering design into elementary school science curricula. [Conference presentation]. American Society for Engineering Education, Singapore

Wilks, S. (1995). Critical \& creative thinking: Strategies for classroom inquiry. Portsmouth, NH: Heinemann.

Willard-Holt, C. \& Bottomley, D. (2000). Reflectivity and effectiveness of preservice teachers in a unique field experience. Action in Teacher Education, 21(2), 76- 89.

Yıldırım, B. (2016). 7. Sinıf fen bilimleri dersine entegre edilmiş fen teknoloji mühendislik matematik (STEM) uygulamaları ve tam ögrenmenin etkilerinin incelenmesi [Yayınlanmamış doktora tezi]. Gazi Üniversitesi Eğitim Bilimleri Enstitüsü.

Yıldırım, B. \& Altun, Y. (2015). STEM eğitim ve mühendislik uygulamalarının fen bilgisi laboratuar dersindeki etkilerinin incelenmesi. El-Cezeri Fen ve Mühendislik Dergisi. 2(2), 28-40.

Yıldırım, B., Şahin, E. \& Tabaru, G. (2017, August). The effect of stem practıces on pre-service teachers"beliefs on nature of sclence, their attitudes towards sclentific research and constructivist approach [Conference Presentation]. In International Congress Of Eurasian Social Sciences (ICOESS).

Y1lmaz, A., Gülgün, C. \& Çağlar, A. (2017). Teaching with STEM applications for 7th class students unit of "Force and Energy": Let's make a parachute, water jet, catapult, intelligent curtain and hydraulic work machine (bucket machine) activities. Journal of Current Researches on Educational Studies, 7(1), 98-116. 